\title{
Natural Products as Leads to Potential Mosquitocides
}

Navneet Kishore, ${ }^{\mathrm{a}}$ Bhuwan B Mishra, ${ }^{\mathrm{b}}$ Vinod K Tiwari, ${ }^{\mathrm{b}}$ Vyasji Tripathi, ${ }^{\mathrm{b}}$ \& Namrita Lall ${ }^{\mathrm{a}^{*}}$

${ }^{a}$ Department of Plant Science, Plant Science Complex, University of Pretoria, Pretoria-0002, South Africa

${ }^{b}$ Department of Chemistry, Centre of Advanced Study, Faculty of Science, Banaras Hindu University, Varanasi221005, India

\begin{abstract}
Mosquitoes are the crucial vectors for a number of mosquito-borne infectious diseases i.e. dengue, yellow fever, chikungunya, malaria, Rift Valley fever, elephantiasis, Japanese Encephalitis, and Murray Valley encephalitis etc. Besides, they also transmit numerous arboviruses (arthropod-borne viruses) for example West Nile virus (WNV), Saint Louis encephalitis virus, Eastern equine encephalomyelitis virus (EEE), Everglades virus (EVEV), Highlands J (HJ) virus, and La Crosse Encephalitis virus. The emergence of widespread insecticide resistance and the potential environmental issues associated with some synthetic insecticides (such as DDT) has indicated that additional approaches to control the proliferation of mosquito population would be an urgent priority research. The present review highlights some natural product mosquitocides that are target-specific, biodegradable, environmentally safe, and botanicals in origin.
\end{abstract}

Key words: Mosquitocides, Medicinal Plants, Natural Products

Corresponding Author: Prof. Namrita Lall

Department of Plant Science,

University of Pretoria, Pretoria-0002

South Africa

E-mail: Namrita.Lall@up.ac.za

Phone: +27-12-420-2524

Fax: +27-12-362-5099 


\section{INTRODUCTION}

Mosquitoes, the flying insects of family Culicidae, are crucial vectors for a number of mosquito-borne infectious diseases that are maintained in nature through the biological transmission by blood feeding mosquitoes to susceptible vertebrate hosts causing dengue, yellow fever, malaria and filariasis in the American tropics; Rift Valley fever, elephantiasis, Japanese Encephalitis, chikungunya, malaria and filariasis in Africa and Asia; and Murray Valley encephalitis in Australia. They are also known to transmit numerous arboviruses (arthropod-borne viruses) for example West Nile virus (WNV), Saint Louis encephalitis virus, Eastern equine encephalomyelitis virus (EEE), Everglades virus (EVEV), Highlands J (HJ) virus, La Crosse Encephalitis virus in the United States etc.

Vector control is by far the most successful method for reducing incidences of mosquito born diseases. The discovery of DDT's and the subsequent development of organochlorines, organophosphates and pyrethroids suppressed natural product research, as the problem for insect control were thought be solved. However, high cost of synthetic pyrethroids, environment and food safety concerns, unacceptability and toxicity of many organophosphates and organochlorines, and a global increase in insecticidal resistance, have argued for stimulated research towards the development of potential insecticides of botanic origin (Severini et al. 1993).

The use of herbal products is one of the best alternatives for mosquito control. The search for herbal preparations and pure compounds that do not produce adverse effects in the nontargeted organisms, along with the benign environmental characteristics, remain a top priority research for scientists associated with the development of alternative vector control measures (Chowdhury et al. 2008). Many plant species are known to possess biological activity that is frequently assigned to the secondary metabolites. Among these, essential oils and their constituents have received considerable attention in the search for new biopesticides. Many of them have been found to possess an array of properties, including insecticidal activity, 
repellency, feeding deterrence, reproduction retardation, and insect growth regulation against various mosquito species (Rice and Coats 1994; Isman 2000; Cheng et al. 2004; Traboulsi et al. 2005; Yang et al. 2005). The present review covers the entire formal and constant research on mosquitocidal natural products reported in literature from the 1947 to late 2012 with a sufficient focus on structure activity relationship (SAR) and mechanism of action.

\section{TRADITIONAL MOSQUITO REPELLENTS AND USAGE CUSTOM}

The phytochemicals have received considerable renewed attention as potential bioactive agents for insect vector management. However, there is a little other than anecdotal, traditional, or cultural evidence on this topic (Grodner 1997). The Greek natural philosopher Pliny the Elder (1'st century AD) recorded all the known pest control methods in "Natural History'. The use of powdered chrysanthemum as a significant insecticide was traced from Chinese record. Pyrethrum extracted from flowers was sprayed in houses as a short-term knockdown insecticide. The other natural products like derris, quassia, nicotine, hellebore, anabasine, azadirachtin, $d$-limonene, camphor, and turpentine were among some important phytochemical insecticides widely used in developed countries (Wood 2003).

There are several reports, particularly in Africa that describe the buring of plant materials to drive away mosquitoes. Thirteen percent of rural Zimbabweans use plants (Lukwa et al. 1999) while $39 \%$ of Malawians burn wood dung or leaves (Ziba et al. 1994). Up to $100 \%$ of Kenyans burn plants to repel mosquitoes (Seyoum et al. 2002), and in Guinea Bissau, about $55 \%$ of people burn plants or hang them in the home to repel mosquitoes (Palsson and Jaenson 1999). The local communities adapt various methods to repel mosquitoes. Application of smoke by burning the plant parts is one of the most common practices among the local inhabitants. Other types of applications are spraying the extracts by crushing and grinding the repellent plant parts, hanging and sprinkling the repellent plant leaves on the floor etc. The leaf of repellent plant is one of the commonly and extensively used plant parts to repel the insects and mosquitoes, followed by root, flower, and remaining parts of repellent 
plants. Various traditional repellent plants used by the local inhabitants to avoid mosquito bites have been listed in Table 1 .

Table 1: Traditional plants as mosquito repellents (Karunamoorthi et al. 2009)

\begin{tabular}{lll}
\hline Traditional Names & Scientific Names & Family \\
\hline Tinjut & Ostostegia integrifolia & Lamiaceae \\
Woira & Olea europaea & Oleaceae \\
Neem & Azadirachta indica & Meliaceae \\
Wogert & Silene macroserene & Caryophyllaceae \\
Kebercho & Echinops sp. & Asteraceae \\
Waginos & Brucea antidysenterica & Simaroubaceae \\
Eucalyptus & Eucalyptus camaldulensis & Myrtaceae \\
Ades & Myrtus communis & Myrtaceae \\
Gemmero & Capparis tomentosa & Capparidaceae \\
Tej-sar & Cymbopogen citrates & Rutaceae \\
Ats-faris & Datura stramonium & Solanaceae \\
Endode & Phytolacca dodecandra & Phytolaccaceae \\
Azo-hareg & Clematis hirsuta & Ranunculaceae \\
Berberra & Millettia ferruginea & Fabaceae \\
Gullo & Ricinus communis & Euphorbiaceae \\
\hline
\end{tabular}

\section{PLANTS WITH POTENTIAL MOSQUITOSIDAL PROPERTIES}

The search for natural and benign envornmental mosquiotsides is ongoing worldwide (Kuo et al. 2007; Balandrin et al. 1985; Ghosh and Chandra 2006). Insecticidal effects of plant extracts vary not only according to plant species, mosquito species and plant parts, but also to extraction methodology (Swain 1977). A brief delve into the literature reveals that many applied investigations (Perrucci et al. 1997; Lee et al. 2001; Nawamaki and Kuroyanagi 1996) sofar have been made towards biological screening of botanic extracts against a large 
number of pathogens and arthropods. However, the lack of reviews in concerned area is highly surprising since much of efforts have been invested in locating mosquitocidal phytochemicals from edible crops, ornamental plants, herbs, grasses, tropical and subtropical trees and marine angiosperms. A review by Roark (1947) estimates about 1200 plant species with a wide spectrum of bioactive insecticides. Similarly, a review by Sukumar et al. (1991) lists about 344 insecticides of botanical origin. Other reviews by Schmutterer (1990), Mulla and Su (1999), Ghosh et al. (2012) and Boulogne et al. (2012) could not cover significant topics such as mode \& site of action and joint action of botanical extracts with other phytochemicals and synthetic insecticides. The botanical extracts with promicing mosquitosidal effects have been summarized in Table 2.

Table 2: Mosquitocidal activity of crude plant extracts

\begin{tabular}{|c|c|c|c|c|}
\hline Plant Family & Plant Species & Plant Parts & Mosquitos species & References \\
\hline Acanthaceae & Rhinocanthus nasutus & Leaf & $\begin{array}{l}\text { Ae. aegypti } \\
\text { An. Stephensi } \\
\text { Cx. quinquefasciatus }\end{array}$ & $\begin{array}{l}\text { Pushpalatha and } \\
\text { Muthukrishnan (1999) }\end{array}$ \\
\hline & $\begin{array}{l}\text { Hygrophila auriculata } \\
\text { Justicia adhatoda }\end{array}$ & $\begin{array}{l}\text { Shoot } \\
\text { Leaf }\end{array}$ & $\begin{array}{l}\text { Cx. quinquefasciatus } \\
\text { Cx. quinquefasciatus }\end{array}$ & Nazar et al. (2009) \\
\hline Acoraceae & Acorus calamus & Rhizome & $\begin{array}{l}\text { Cx. quinquefasciatus } \\
\text { Ae. aegypti } \\
\text { Ae. albopictus } \\
\text { An. tessellates } \\
\text { An. subpictus } \\
\text { Cx. fatigans }\end{array}$ & $\begin{array}{l}\text { Ranaweera (1996), } \\
\text { Sharma et al. (1994) }\end{array}$ \\
\hline Agavaceae & Agave sisalana & Fiber & Cx. pipiens & Pizarro et al. (1999) \\
\hline Alliaceae & Allium sativa & Bulb & Cx. pipiens & $\begin{array}{l}\text { Thomas and Callaghan } \\
\text { (1999) }\end{array}$ \\
\hline Anacardiaceae & $\begin{array}{l}\text { Mentha } \\
\text { microcorphylla }\end{array}$ & Leaf & An. Stephensi & Ghosh et al. (2008) \\
\hline
\end{tabular}




\begin{tabular}{|c|c|c|c|c|}
\hline & Pistacia lentiscus & Leaf & An. Stephensi & \\
\hline \multirow[t]{11}{*}{ Annonaceae } & Annona squamosa & Leaf & Ae. aegypti & Monzon et al. (1994) \\
\hline & & & Cx. quinquefasciatus & \\
\hline & Annona squamosa & Bark & Cx. quinquefasciatus & Kamaraj et al. (2010) \\
\hline & & & An. stephensi & \\
\hline & Annona glabra & Seed & Ae. aegypti & \\
\hline & Annona muricata & Root & Ae. aegypti & \\
\hline & Annona squamosa & Root & Ae. aegypti & Omena et al. (2007) \\
\hline & Annona crassiflora & Root wood & Ae. aegypti & \\
\hline & Mkilua fragrans & Aerial Part & An. gambiae & \\
\hline & Xylopia caudata & Leaf & Ae. aegypti & Zaridah et al. (2006) \\
\hline & Xylopia ferruginea & Leaf & Ae. aegypti & \\
\hline \multirow[t]{2}{*}{ Apiaceae } & Daucus carota & Seeds & Ae. Aegypti, & Sharma et al. (1994) \\
\hline & & & Cx. fatigans & \\
\hline \multirow[t]{4}{*}{ Apocynaceae } & Calotropis procera & Root & An. labranchiae & Markouk et al. (2000) \\
\hline & Catharanthus roseus & Whole & Cx. quinquefasciatus & Nazar et al. (2009) \\
\hline & Rhazya Stricta & Leaf Acute & Cx. pipens & \\
\hline & Solenostemma argel & Aerial parts & Cx. pipens & Al-Doghairi et al. (2004) \\
\hline Araceae & Homalomena & Rhizome & Ae. aegypti & Al-Doghairi et al. (2004) \\
\hline & propinqua & & & \\
\hline Aristolochiaceae & Aristolochia saccata & Root & Cx. pipens & Das et al. (2007) \\
\hline \multirow[t]{3}{*}{ Asclepiadaceae } & Pergularia extensa & Leaf & Cx. pipens & Das et al. (2007) \\
\hline & Hemidesmus indicus & Root & Cx. quinquefasciatus & Khanna and Kannabiran \\
\hline & Gymnema sylvestre & Leaf & Cx. quinquefasciatus & $(2007)$ \\
\hline \multirow[t]{2}{*}{ Asphodelaceae } & Aloe ngongensis & Leaf & An. gambie & Matasyoh et al. (2008) \\
\hline & Aloe turkanensis & Leaf & An. gambiae & Matasyoh et al. 2008 \\
\hline \multirow[t]{3}{*}{ Asteraceae } & Anthemis nobilis & Flower & CX. pipiens & Soliman and El-Sherif \\
\hline & & & & (1995) \\
\hline & Baccharis spartioides & Aerial Part & Ae. aegypti & Gillij et al. (2008) \\
\hline
\end{tabular}




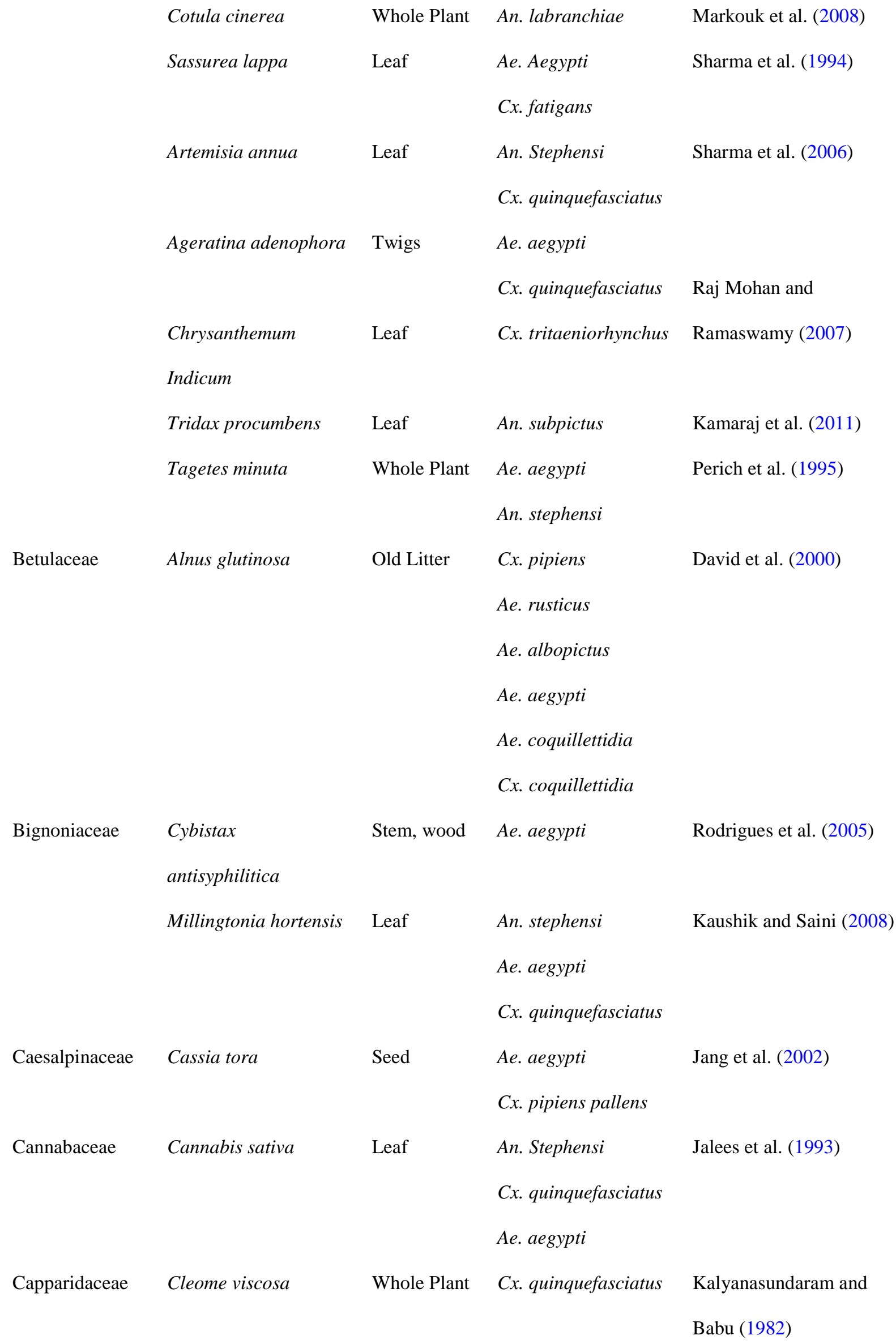




\begin{tabular}{|c|c|c|c|c|}
\hline Caricaceae & Carica papaya & Seed & Cx. quinquefasciatus & Rawani et al. (2009) \\
\hline Caryophyllaceae & Dictyota caryophyllum & Flower & Ae. aegypti & Tunon et al. (2006) \\
\hline \multirow[t]{2}{*}{ Caulerpaceae } & Caulerpa & Whole Plant & Ae. aegypti & Thangam and Kathiresan \\
\hline & scalpelliformis & & & (1991) \\
\hline \multirow[t]{3}{*}{ Clusiaceae } & Calophyllum & Leaf and & Cx. quinquefasciatus & Pushpalatha and \\
\hline & inophyllum & Seeds & An. Stephensi & Muthukrishnan (1999) \\
\hline & & & Ae. aegypti & \\
\hline \multirow[t]{18}{*}{ Cucurbitaceae } & Bryonopsis laciniosa & Whole Plant & Cx. quinquefasciatus & Kabir et al. (2003) \\
\hline & Momordica charantia & Fruit & An. stephensi & Singh et al. (2006) \\
\hline & & & Cx. quinquefasciatus & \\
\hline & & & Ae. aegypti & \\
\hline & Momordica charantia & Leaf & Cx. quinquefasciatus & Prabhakar and Jebanesa \\
\hline & Trichosanthes anguina & & & (2004) \\
\hline & Luffa acutangula & & & \\
\hline & Benincasa cerifera & & & \\
\hline & Citrullus vulgaris & & & \\
\hline & Coccinia indica & Leaf & Cx. quinquefasciatus & Rahuman and Venkatesan \\
\hline & Cucumus sativus & & Ae. aegypti & (2008) \\
\hline & Coccinia indica & Leaf & Ae. albopictus & \\
\hline & Cucumis sativus & & & \\
\hline & Momordica charantia & & & \\
\hline & Gymnopetelum & Fruit \& & Ae. albopictus & \\
\hline & cochinchinensis & Pericarp & & \\
\hline & Citrullus vulgaris & Leaf & Ae. stephensi & Mullai et al. (2008) \\
\hline & Citrullus vulgaris & Leaf & Ae. aegypti & Mullai \& Jebanesan (2007) \\
\hline \multirow[t]{2}{*}{ Cupressaceae } & Callitris glaucophylla & Wood & Ae. aegypti & Shaalan et al. (2003) \\
\hline & & & Cx. annulirostris & \\
\hline \multirow[t]{2}{*}{ Dictyotaceae } & Dictyota dichotoma & Whole Plant & Ae. aegypti & Kalyanasundaram and \\
\hline & & & & Babu (1982) \\
\hline Euphorbiaceae & Codiaeum variegatum & Leaf & Ae. Aegypti & Monzon et al. (1994) \\
\hline
\end{tabular}




\begin{tabular}{|c|c|c|c|c|}
\hline & & & Cx. quinquefasciatus & \\
\hline & Jatropha curcus & Leaf & Cx. quinquefasciatus & Karmegam et al. (1997) \\
\hline & Euphorbia hirta & Stembark & Cx. quinquefasciatus & Rahuman and Venkatesan \\
\hline & E. tirucalli & Stem bark & Cx. quinquefasciatus & (2008) \\
\hline & Acalypha alnifolia & Leaf & An. Stephensi & Kovendan (2012) \\
\hline & & & Ae. aegypti & \\
\hline & & & Cx. quinquefasciatus & \\
\hline & Acalypha indica & Leaf & An. stephensi & Govindarajan et al. (2008) \\
\hline & Cleistanthus collinus & Leaf & An. gambiae & \\
\hline & Ricinus communis & Whole Plant & An. stephensi & Sakthivadivel and Daniel \\
\hline & & & & (2008) \\
\hline Fabaceae & Abrus precatorius & Shoot & Cx. quinquefasciatus & Nazar et al. (2009) \\
\hline & Acacia nilotica & Leaf & An. gambiae & Kumar and Dutta (1987) \\
\hline & Cassia obtusifolia & Seed & Ae. aegypti & Jang et al. (2002) \\
\hline & & & Cx. pipiens pallens & \\
\hline & Croton & Shoot & Cx. quinquefasciatus & Nazar et al. (2009) \\
\hline & bonplandianum & & & \\
\hline & Vicia tetrasperma & Seed & Cx. pipiens pallens & Jang et al. (2002) \\
\hline Geraniaceae & Pelargonium citrosum & Whole Plant & Ae. aegypti & Zaridah et al. (2006) \\
\hline Labiatae & Endostemon & Aerial Parts & An. gambiae & Odalo et al. (2005) \\
\hline & tereticaulis & & & \\
\hline & Lavandula afficinalis & Whole Plant & An. stephensi & Sakthivadivel and Daniel \\
\hline & & & & $(2008)$ \\
\hline & Leucas aspera & Whole & Cx. quinquefasciatus & Nazar et al. (2009) \\
\hline & Mentha arvensis & Whole Plant & An. stephensi & Sakthivadivel and Daniel \\
\hline & & & & (2008) \\
\hline & Mentha piperita & Aerial Parts & Ae. aegypti & Hori (2003) \\
\hline & & & An. Tessellatus & \\
\hline & & & Cx. quinquefasciatus & \\
\hline & Minthostachys setosa & Whole Plant & Ae. aegypti & Ciccia et al. (2000) \\
\hline
\end{tabular}




\begin{tabular}{|c|c|c|c|c|}
\hline & Moschosma & Leaf & Cx. quinquefasciatus & Zaridah et al. (2006) \\
\hline & polystachyum & & & \\
\hline & Ocimum basilicum & Aerial Parts & An. stephensi & Kalyanasundaram and \\
\hline & & & Ae. aegypti & Babu (1982), Nerio et al. \\
\hline & & & Cx. quinquefasciatus & $(2010)$ \\
\hline & & & Cx. pipiens & \\
\hline & Ocimum gratissimum & Leaf & Cx. gelidus & Kamaraj et al. (2010) \\
\hline & & & Cx. quinquefasciatus & \\
\hline & Ocimum sanctum & Leaf & Ae. aegypti & Anees (2008) \\
\hline & & & Cx. quinquefasciatus & \\
\hline & Origanum majoranal & Leaf & Cx. pipiens & Soliman and El-Sherif \\
\hline & & & & (1995) \\
\hline & Plectranthus longipes & Aerial Parts & An. gambiae & Nerio et al. (2010) \\
\hline & Pogostemon cablin & Leaf & Ae. aegypti & Trongtokit et al. (2005) \\
\hline & & & $\begin{array}{l}\text { Cx. quinquefasciatus } \\
\text { An. dirus }\end{array}$ & \\
\hline & Rosmarinus officinalis & Shoot & An. stephensi & Prajapati et al. (2005) \\
\hline & & & Ae. aegypti & \\
\hline & & & Cx. quinquefasciatus & \\
\hline & Thymus capitatus & Whole Plant & Cx. pipiens & Mansour et al. (2000) \\
\hline Lauraceae & Cinnamomum iners & Leaf & Ae. aegypti & \\
\hline & Cinnamomиm & Leaf & Ae. aegypti & \\
\hline & kuntsleri & & & \\
\hline & Cinnamomum & Leaf \& Bark & Ae. aegypti & \\
\hline & pubescens & & & Zaridah et al. (2006) \\
\hline & Cinnamomum & Bark & Ae. aegypti & \\
\hline & scortechinii & & & \\
\hline & Cinnamomum sintoc & Bark, Leaf & Ae. aegypti & \\
\hline & Cinnamomum & Bark, Leaf & An. stephensi & Prajapati et al. (2005) \\
\hline & zeylanicum & & Ae. aegypti & \\
\hline
\end{tabular}




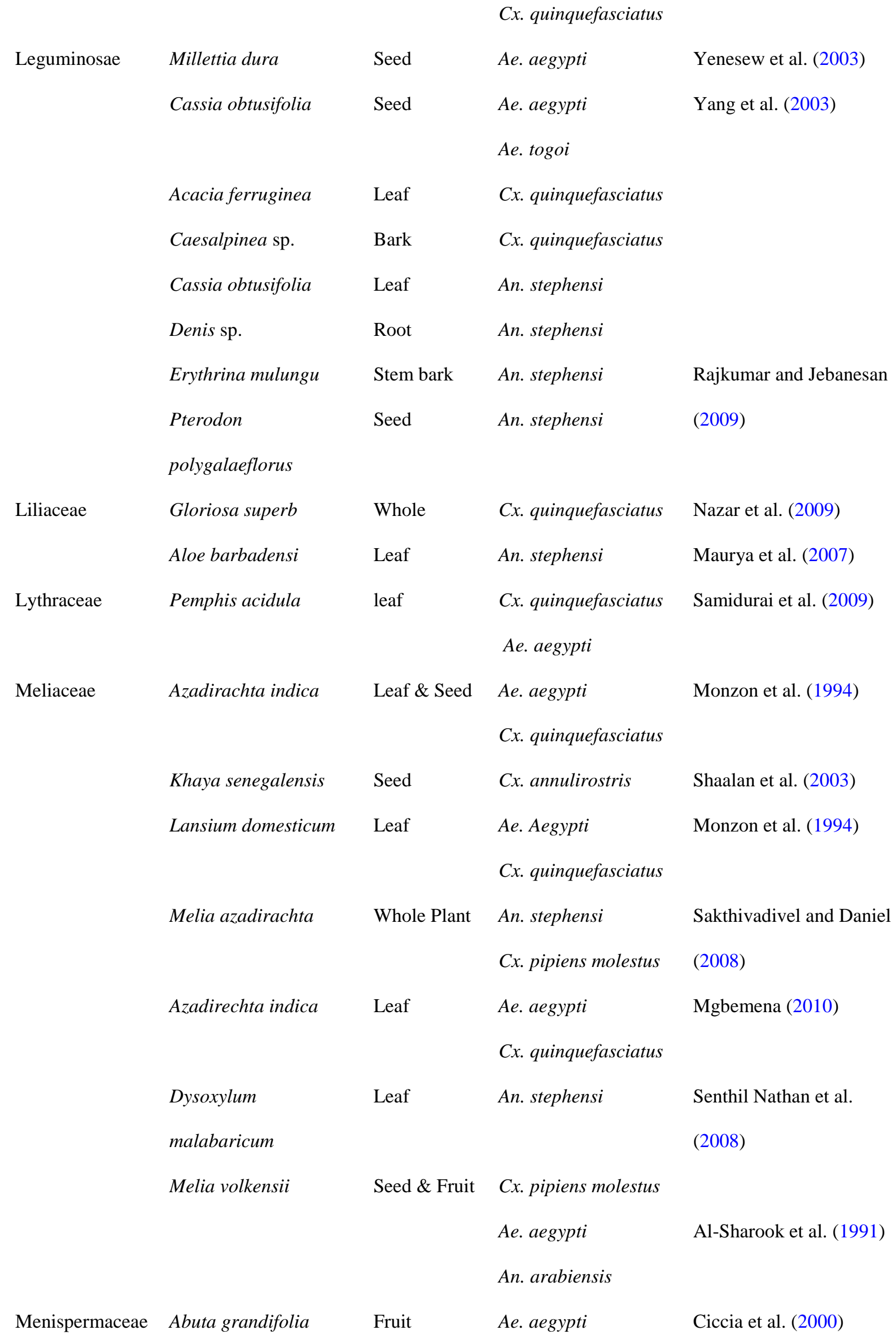




\begin{tabular}{|c|c|c|c|c|}
\hline Moringaceae & Moringa oleifera & Bark & Cx. gelidus & $\begin{array}{l}\text { Kamaraj and Rahuman } \\
\text { (2010) }\end{array}$ \\
\hline \multirow[t]{4}{*}{ Myrtaceae } & $\begin{array}{l}\text { Eucalyptus } \\
\text { camaldulensis }\end{array}$ & Fruit & $C x$. pipiens & Erler et al. (2006) \\
\hline & Eugenia caryophyllus & Whole Plant & An. stephensi & $\begin{array}{l}\text { Sakthivadivel and Daniel } \\
\text { (2008) }\end{array}$ \\
\hline & Eucalyptus globules & Whole Plant & $\begin{array}{l}\text { An. stephensi } \\
\text { Ae. albopictus }\end{array}$ & $\begin{array}{l}\text { Soliman and El-Sherif } \\
\text { (1995) }\end{array}$ \\
\hline & Syzygium aromaticum & Leaf & $\begin{array}{l}\text { Ae. aegypti } \\
\text { Cx. quinquefasciatus } \\
\text { An. dirus }\end{array}$ & Trongtokit et al. (2005) \\
\hline Oleaceae & Jasminum fructicans & Leaf & Cx. pipiens & $\begin{array}{l}\text { Soliman and El-Sherif } \\
\text { (1995) }\end{array}$ \\
\hline Papaveraceae & Argemone mexicana & Leaf & Cx. quinquefasciatus & Karmegam et al. (1997) \\
\hline Pinaceae & Cedrus deodara & Whole Plant & An. stephensi & $\begin{array}{l}\text { Sakthivadivel and Daniel } \\
\text { (2008) }\end{array}$ \\
\hline \multirow[t]{5}{*}{ Piperaceae } & Piper longum & Fruit & CX.pipiens pallens & Vasudevan et al. (2009) \\
\hline & Piper nigrum & Fruit & $\begin{array}{l}\text { Cx. pipiens pallens } \\
\text { Ae. aegypti } \\
\text { Ae. togoi }\end{array}$ & Moawed (1998) \\
\hline & Piper longum & $\begin{array}{l}\text { Fruit } \\
\text { exocarp }\end{array}$ & Ae. aegypti & Chaithong et al. (2006) \\
\hline & P. ribesoides & $\begin{array}{l}\text { Fruit } \\
\text { exocarp }\end{array}$ & Ae. aegypti & \\
\hline & P. sarmentosum & $\begin{array}{l}\text { Fruit } \\
\text { exocarp }\end{array}$ & Ae. aegypti & \\
\hline \multirow[t]{2}{*}{ Plumbaginaceae } & $\begin{array}{l}\text { Plumbago dawei } \\
\text { Plumbago stenophylla }\end{array}$ & $\begin{array}{l}\text { Root } \\
\text { Root }\end{array}$ & $\begin{array}{l}\text { An. gambiae } \\
\text { An. gambiae }\end{array}$ & Dorni et al. (2007) \\
\hline & Plumbago zeylanica & Root & An. gambiae & Maniafu et al. (2009) \\
\hline Poaceae & Cymbopogon citratus & Whole Plant & Cx. quinquefasciatus & Zaridah et al. (2006) \\
\hline
\end{tabular}


Cymbopogon flexuosus

Cymbopogon martini

Sorghum bicolour

Vetiveria zizanioides

Rhizome

Cx. pipiens

Spermacoce hispida Whole

Peel

Cx. quinquefasciatus

Cx. pipiens

Rutaceae

Citrus limon

Zanthoxyllum

acanthopodium

Feronia limonia

Leaf

Cx. quinquefasciatus

An. stephensi

Citrus sinensis

Atlantia monophylla

Leaf

Whole Plant

Cx. quinquefasciatus

Simaroubaceae

Quassia amara

$\begin{array}{ll}\text { Solanum indicum } & \text { Shoot } \\ \text { S. elaeagnifolium } & \text { Berry } \\ \text { S. sodomaeum } & \text { Seed } \\ \text { S. xanthocarpum } & \text { Leaf }\end{array}$

Fruits

Ae. aegypti

Solanum anthocarpum

Solanum nigrum

S. xanthocarpum
Cx. quinquefasciatus

Cx. pipiens pallens

Leaf

Root

Dried fruit

An. Culicifacies

An. stephensi

Cx. quinquefasciatus

Ae. aegypti

Root
Sakthivadivel and Daniel

Jackson et al. (1990)

Soliman and El-Sherif

(1995)

Nazar et al. (2009)

Thomas, and Callaghan

Zaridah et al. (2006)

Rahuman et al. (2000)

Bagavan et al. (2009)

Sivagnaname and

Kalyanasundaram (2004)

Rajkumar and Jebanesan

Nazar et al. (2009)

Markouk et al. (2000)

Markouk et al. (2000)

Rajkumar and Jebanesan

Kumar et al. (2012)

Karmegam et al. (1997)

Mohan et al. (2006)

Raghavendra et al. (2009)

Mohan et al. (2006) 


\begin{tabular}{|c|c|c|c|c|}
\hline & \multirow{2}{*}{$\begin{array}{l}\text { Solanum villosum } \\
\text { Cestrum diurnum }\end{array}$} & \multirow{2}{*}{$\begin{array}{l}\text { Leaf } \\
\text { Leaf }\end{array}$} & \multirow{2}{*}{$\begin{array}{l}\text { An. subpictus } \\
\text { An. stephensi }\end{array}$} & \multirow{2}{*}{$\begin{array}{l}\text { Chowdhury et al. (2009) } \\
\text { Ghosh \& Chandra (2006) }\end{array}$} \\
\hline & & & & \\
\hline & Solanum villosum & Berry & Ae. aegypti & Chowdhury et al. (2008a) \\
\hline & Solanum nigrum & Leaf & Cx. quinquefasciatus & Rawani et al. (2010) \\
\hline & Solanum villosum & Leaf & An. Stephensi & Chowdhury et al. (2008b) \\
\hline & & & Cx. quinquefasciatus & \\
\hline & Solanum nigrum & Dried fruit & An. culicifacies A & Raghavendra et al. (2009) \\
\hline & & & An. Culicifacies $\mathrm{C}$ & \\
\hline & & & An. Stephensi & \\
\hline & & & Cx. quinquefasciatus & \\
\hline & & & Ae. aegypti & \\
\hline \multirow[t]{2}{*}{ Thymelaeaceae } & Aquilaria malaccensis & Wood & Ae. aegypti & Zaridah et al. (2006) \\
\hline & Dirca palustris & Seed & Ae. aegypti & Ramsewak et al. (1999) \\
\hline \multirow[t]{5}{*}{ Umbelliferae } & Angelico glauca & Aerial Parts & Ae. aegypti & Sharma et al. (1994) \\
\hline & & & Cx. fatigans & \\
\hline & Centella asiatica & Leaf & Cx. quinquefasciatus & Rajkumar and Jebanesan \\
\hline & & & & $(2005)$ \\
\hline & Pimpinella anisum & Seed & Cx. pipiens & Erler et al. (2006) \\
\hline Valerianaceae & Valarian wallichii & Rhizome & Ae. Aegypti & Sharma et al. (1994) \\
\hline & & & Cx. fatigans & \\
\hline \multirow[t]{6}{*}{ Verbenaceae } & Aloysia citriodora & Whole Plant & Ae. aegypti & Gillij et al. (2008) \\
\hline & Clerodendrun inerme & Leaf & Cx. quinquefasciatus & \\
\hline & Stachytarpheta & Shoot & Cx. quinquefasciatus & Nazar et al. (2009) \\
\hline & jamaicensis & & & \\
\hline & Vitex nequrdo & Whole Plant & Cx. quinquefasciatus & Kalyanasundaram and \\
\hline & & & & Babu (1982) \\
\hline \multirow[t]{4}{*}{ Zingiberaceae } & Curcuma domestica & Rhizome & An. culicifacies & Ranaweera (1996) \\
\hline & Curcuma aromatica & Rhizome & Ae. aegypti & Choochate et al. (2005) \\
\hline & Kaempferia galanga & Whole & Cx. quinquefasciatus & Nazar et al. (2009) \\
\hline & Zingiber officinalis & Tubers & Cx. quinquefasciatus & Pushpanathan et al. (2008) \\
\hline
\end{tabular}




\section{PLANT DERIVED MOSQUITOSIDAL AGENTS}

Natural product literature provides a growing research on plant derived mosquitosidal agents. Mosquitoes in the larval stage are attractive targets for pesticides because they breed in water and, thus, are easy to deal with them in this habitat. Some of new significant larvicidal insect growth regulators such as methoprene, pyriproxyfen, diflubenzuron, and endotoxins obtained from Bacillus thuringiensis israelensis and B. sphaericus have been developed. The plant Azardichita indica has gained wide acceptance in some countries as an antifeedant (Isman 1997). Many of essential oils such as citronella, calamus, thymus, and eucalyptus have been found promising in killing of mosquito larva (Shaalan et al. 2005; Rahuman et al. 2008; James 1992; Hemingway 2004; Wandscheer et al. 2004). Hence, in the coming sections numerous plants derived natural products with mosquitosidal potentials have been discussed. In order to highlight any possible mechanism based activity the review has been organized in accordance to chemical structural classes.

\section{Alkanes, alkenes, alkynes and simple aromatics}

Octacosane (1), a hydrocarbon isolated from Moschosma polystachyum, exhibits significant larvicidal activity against $C x$. quinquefasciatus mosquito with $\mathrm{LC}_{50}$ value of $7.2 \pm 1.7 \mathrm{mg} / \mathrm{L}$ (Rajkumar and Jebanesan 2004). The (E)-6-hydroxy-4,6-dimethyl-3-heptene-2-one isolated from Ocimum sanctum, displays toxicity against fourth-instar larvae of Ae. aegypti with $\mathrm{LD}_{100}$ value of $6.25 \mu \mathrm{g} / \mathrm{mL}$ in $24 \mathrm{~h}$ (Kelm and Nair 1998). Among the acetylenic compounds, falcarinol (3) and falcarindiol (4) isolated from Cryptotaenia Canadensis, demonstrate strong activity against $C x$. pipiens larvae (Kern and Cardellina 1982; Miyazawa et al. 1996). The more lipophilic compound $\mathbf{3}$ exerts strong toxicity than the more polar acetylene 4 with LC $_{50}$ values of 3.5 and 2.9 ppm in $24 \mathrm{~h}$ and $48 \mathrm{~h}$, respectively (Eckenbach at al. 1999). The volatile aromatics, 4-ethoxymethylphenol (5), 4-butoxymethylphenol (6), vanillin (7), 4-hydroxy-2-methoxycinnamaldehyde (8), and 3,4-dihydroxyphenylacetic acid (9), isolated from Vanilla fragrans, show very efficient mortality against mosquito larvae. 
The compounds 5-8 display $100 \%$ larval mortality at $0.5,0.4,2.0$ and $1.0 \mathrm{mg} / \mathrm{mL}$ concentrations, respectively while compound $\mathbf{9}$ shows $17 \%$ larval mortality at a concentration of $1.0 \mathrm{mg} / \mathrm{mL}$ (Sun et al. 2001). The hexane extract of Delphinium cultorum containing ethylmethylbenzene (10), 1-isopentyl-2,4,5-trimethylbenzene (11), 2-(hex-3-ene-2one)phenyl methyl ketone (12), $E \& Z$ 3-butylidene-3H-isobenzofuran-1-one (13 and 14) and 2-penten-1-ylbenzoic acid (15), exhibits $100 \%$ mortality against Ae. aegypti larvae at 10 $\mathrm{mg} / \mathrm{mL}$ in $2 \mathrm{~h}$ (Miles et al. 2000).

The trans-asarone (16) isolated from seeds of Daucus carota, shows $100 \%$ mortality of fourth-instar larvae of Ae. aegypti at $200 \mu \mathrm{g} / \mathrm{mL}$ concentration (Momin and Nair 2002). The compound 17 isolated from rhizomes of Curcuma longa, display 100\% mortality against $A$. aegyptii larvae with $\mathrm{LD}_{100}$ value of $50 \mu \mathrm{g} / \mathrm{mL}$ in $18 \mathrm{~h}$ (Lee et al. 2001). Similarly, compound 18 isolated from Ocimum sanctum, displays activity against fourth-instar larvae of Ae. aegypti with $\mathrm{LD}_{100}$ value of $200 \mu \mathrm{g} / \mathrm{mL}$ in $24 \mathrm{~h}$ (Kelm and Nair 1998). The 5-allyl-2methoxyphenol (19) isolated from seeds of Apium graveolens, exhibit 100\% mortality on fourth-instar Ae. aegypti larvae at $200 \mu \mathrm{g} / \mathrm{mL}$ concentration (Momin et al. 2000). The transanethole (20), methyl eugenol (21) and iso-methyl eugenol (22) isolated from Myrica salicifolia, exhibit $100 \%$ mortality with $\mathrm{LD}_{100}$ value of 20,60 and $80 \mathrm{ppm}$ in 24 h against 4 th instar larvae of Ae. aegypti (Kelm et al. 1997). Methyl-phydroxybenzoate (23) isolated from Vitex trifolia, shows $100 \%$ larval mortality at 20 ppm against $C x$. quinquefasciatus and Ae. aegypti with $\mathrm{LC}_{50}$ values of 5.77 and 4.74 ppm, respectively (Kannathasan et al. 2011).

The stilbenes 24-30 isolated from the root bark of Lonchocarpus chiricanus possess larvicidal activities against Ae. aegypti. Among these, compound 28 exhibits highest activity at $3.0 \mathrm{ppm}$ while 25 \& 26 at 6.0 ppm concentration display pronounced affect by kill all the larvae in 24 h. The compounds $\mathbf{2 4 , 2 7 , 2 9}$ and $\mathbf{3 0}$ at about 50 ppm concentration display moderate activity against larvae of Ae. aegypti (Ioset et al. 2001). 
<smiles>[R]C(/C=C\CCCCCC)/C=C/C#CC(O)C=C</smiles><smiles>CCCCCCOCc1ccc(O)cc1COCCCCCOc1ccc(C=O)cc1OC</smiles><smiles>CC(=O)/C=C/CCc1ccccc1C(C)=O</smiles>

11

12<smiles>CC/C=C\C=C/CCC</smiles><smiles>O=C(O)c1ccccc1/C=C/CCCl</smiles><smiles>C/C=C/c1cc(OC)c(OC)cc1OC</smiles><smiles>C=CC(=O)CC(C)c1ccc(C)cc1</smiles><smiles>CCC/C=C1\OC(=O)c2ccccc21</smiles><smiles>C=CCc1ccc(OC)c(O)c1</smiles><smiles>C/C=C\c1ccc(OC)cc1</smiles>

16<smiles>C=CC(=O)/C=C(/C)c1ccc(C)cc1</smiles><smiles>C=CCc1ccc(OC)c(OC)c1</smiles><smiles>C/C=C\c1ccc(OC)c(OC)c1</smiles><smiles>COC(=O)c1ccc(O)cc1</smiles>

21

22

23<smiles>[R]c1c(O)cc(OC)c([R])c1/C=C/c1ccccc1</smiles>

$24 \mathrm{R}_{1}=\mathrm{H} ; \mathrm{R}_{2}=-\mathrm{CH}_{2} \mathrm{CHC}\left(\mathrm{CH}_{3}\right)_{2}$<smiles>CCc1c(O)cc(/C=C/c2ccccc2)cc1O</smiles><smiles>C=C(C)C</smiles><smiles>CC(C)(C)CO</smiles>

26<smiles>[R]c1c(O)cc2c(c1/C=C/c1ccccc1)CC(O)C(C)(C)O2</smiles>

\section{Lactones}

The lactones $\mathbf{3 1}$ and 32, isolated from Hortonia floribunda, H. angustifolia and H. ovalifolia, exhibit potent larvicidal activity against the second instar larvae of Ae. aegypti with $\mathrm{LC}_{50}$ 
values of 0.41 and $0.47 \mathrm{ppm}$, respectively (Ratnayake et al. 2001). The 3-n-butyl-4,5dihydrophthalide (33) isolated from seeds of Apium graveolens shows 100\% mortality on fourth-instar Ae. aegypti larvae at $25 \mu \mathrm{g} / \mathrm{mL}$ concentration (Momin et al. 2000). The sedanolide (34) isolated from seeds An. graveolens exhibits $100 \%$ mortality at $50 \mu \mathrm{g} / \mathrm{mL}$ concentrations against fourth-instar larvae of Ae. aegyptii (Momin and Nair 2001).

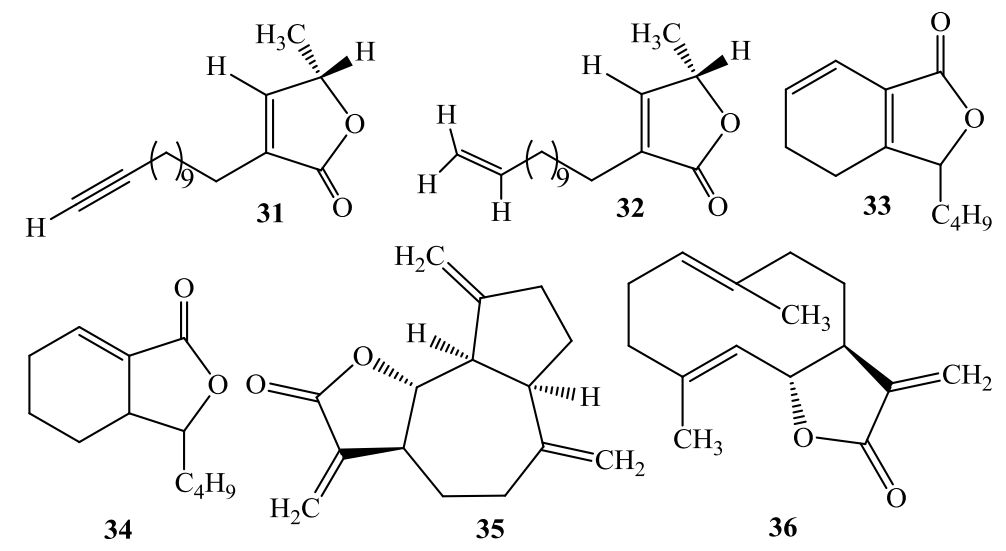

\section{Essential oils and fatty acids}

The essential oil obtained from Saussurea lappa exhibits significant larvicidal effect against A. albopictus $\left(\mathrm{LC}_{50}=12.41 \mu \mathrm{g} / \mathrm{mL}\right)$. The dehydrocostus lactone (35) and costunolide (36), identified from essential oil of S. lappa exhibit strong larvicidal activity against A. albopictus with $\mathrm{LC}_{50}$ values of 2.34 and $3.26 \mu \mathrm{g} / \mathrm{mL}$, respectively (Liu et al. 2012). Likewise, $\alpha$ phellandrene (37), limonene (38), p-cymene (39), $\gamma$-terpinene (40), terpinolene (41) and $\alpha$ terpinene (42) isolated from leaves of Eucalyptus camaldulensis possess significant activity against fourth-instar larvae of Ae. aegypti and Ae. albopictus. The compound 42 exerts the strongest activity against Ae. aegypti larvae with $\mathrm{LC}_{50}$ value of $14.7 \mu \mathrm{g} / \mathrm{mL}\left(\mathrm{LC}_{90}=39.3\right.$ $\mu \mathrm{g} / \mathrm{mL})$, following the compounds $37\left(\mathrm{LC}_{50}=16.6 \mu \mathrm{g} / \mathrm{mL}, \mathrm{LC}_{90}=36.9 \mu \mathrm{g} / \mathrm{mL}\right), 38\left(\mathrm{LC}_{50}=\right.$ $\left.18.1 \mu \mathrm{g} / \mathrm{mL}, \mathrm{LC}_{90}=41.0 \mu \mathrm{g} / \mathrm{mL}\right), 39\left(\mathrm{LC}_{50}=19.2 \mu \mathrm{g} / \mathrm{mL}, \mathrm{LC}_{90}=41.3 \mu \mathrm{g} / \mathrm{mL}\right), \mathbf{4 1}\left(\mathrm{LC}_{50}=\right.$ $\left.28.4 \mu \mathrm{g} / \mathrm{mL}, \mathrm{LC}_{90}=46.0 \mu \mathrm{g} / \mathrm{mL}\right)$ and $40\left(\mathrm{LC}_{50}=30.7 \mu \mathrm{g} / \mathrm{mL}, \mathrm{LC}_{90}>50.0 \mu \mathrm{g} / \mathrm{mL}\right)$ in $24 \mathrm{~h}$ (Jantan et al. 2005). Benzaldehyde (43), 4-hydroxybenzaldehyde (44), benzenepropanal (45), 
cinnamic acid (46), cinnamyl alcohol (47), bornyl acetate (48), $\beta$-caryophyllene (49), caryophyllene oxide (50) and linalool (51), isolated from Cinnamomum osmophloeum display strong activity against Ae. aegypti larvae with $\mathrm{LD}_{50}$ value of $50 \mu \mathrm{g} / \mathrm{mL}$, while $\mathbf{5 2}$ exhibits significant larvicidal effect with $\mathrm{LD}_{50}$ value of $33 \mu \mathrm{g} / \mathrm{mL}$ (Cheng et al. 2009). The $n$ hexadecanoic acid (53) isolated from Feronia limonia leaves shows activity against fourth instar larvae of Cx. quinquefasciatus, An. stephensi and Ae. aegypti, with $\mathrm{LC}_{50}$ values of 129.24, 79.58 and 57.23 ppm, respectively (Rahuman et al. 2000).<smiles>C=C(C)[C]1CC=C(C)CC1</smiles>

37<smiles>CC1=CCC(C(C)C)=CC1</smiles>

39<smiles>CC1=CCC(=C(C)C)CC1</smiles>

41<smiles>CC1=CC=C(C(C)C)CC1</smiles>

42<smiles>O=C(/C=C\c1ccc(CCc2ccccc2)cc1)Oc1ccc(O)cc1</smiles>

43

44

45

46

47<smiles>O=C(Cl)OC/C=C/c1ccccc1</smiles>

52<smiles>C=C1CC/C=C(\C)CC[C@@H]2[C@@H]1CC2(C)C</smiles><smiles>C=C1CC[C@H]2C[C@@](C)(CC[C@H]3[C@H]1CC3(C)C)O2</smiles>

49<smiles>C=Cc1ccc2c(c1)C(=O)CC(C)(C)O2</smiles><smiles>CCCCCCCCCCCCCCCC(=O)O</smiles>

53 $\mathrm{H}_{3} \mathrm{C}\left(\mathrm{H}_{2} \mathrm{C}\right)_{4}\left(\mathrm{HC} / \mathrm{CHCH}_{2}\right)_{2}\left(\mathrm{CH}_{2}\right)_{5} \mathrm{CH}_{2} \mathrm{COOH}$<smiles>C=CCc1ccc(OC)c(OC)c1</smiles><smiles>C/C=C\c1ccc(OC)c(OC)c1</smiles>

$\mathrm{H}_{3} \mathrm{C}(\mathrm{H}_{2} \mathrm{C}_{6} \mathrm{H}_{2} \underbrace{C_{C}}_{\mathrm{H}^{\prime}}=\underbrace{C^{\prime}}_{\mathrm{H}} \mathrm{CH}_{2}\left(\mathrm{CH}_{2}\right)_{5} \mathrm{CH}_{2} \mathrm{COOH}$

59

The aromatics, $O$-methyleugenol (54) and $O$-methylisoeugenol (55) isolated from stem and root barks of Uvariodendron pycnophyllum, exhibit activity against mosquito larvae with $\mathrm{LC}_{50}$ value of 43 and $59 \mathrm{ppm}$ in $24 \mathrm{~h}$, respectively (Kihampa et al. 2010). Likewise, 2,2- 
dimethyl-6-vinylchroman-4-one (56) and 2-senecioyl-4-vinylphenol (57) isolated from the roots of Eupatorium betonicaeforme, possess significant moquitosidal properties. The compound 56 shows efficient larvicidal potential causing $84 \%$ larval mortality at $12.5 \mu \mathrm{g} / \mathrm{mL}$ concentrations while 57 displays $40-100 \%$ mortality at $5-100 \mu \mathrm{g} / \mathrm{mL}$ concentrations (Albuquerque et al. 2004). The fatty acid constituents, linoleic acid (58), and oleic acid (59) isolated from Dirca palustris, exhibit mosquitocidal activity against fourth instar Ae. aegypti larvae with $\mathrm{LD}_{50}$ values of $100 \mu \mathrm{g} / \mathrm{mL}$ at $24 \mathrm{~h}$ (Ramsewak et al. 2001).

\section{Terpenoids}

\section{Monoterpenes}

The monoterpenoids, thymol (60), cholorothymol (61), carvacrol (62), $\beta$-citronellol (63), cinnamaldehyde (64), and eugenol (65) isolated from a number of plant species, possess mosquitocidal activity against forth instar larvae of $C x$. pipiens with $\mathrm{LC}_{50}$ values of 37.95 , 14.77, 44.38, 89.75, 58.97 and $86.22 \mu \mathrm{g} / \mathrm{mL}$, respectively. The $N$-methyl carbamate derivatives of 60-63, i.e. 66-69 display high toxicities against forth instar larvae of $C x$. pipiens with $\mathrm{LC}_{50}$ values of $7.83,11.78,4.54,15.90 \mu \mathrm{g} / \mathrm{mL}$, respectively. Likewise, $N$-methyl carbamate derivatives of geraniol (70) and borneol (71) also exhibit significant activity against forth instar larvae of $C x$. pipiens with $\mathrm{LC}_{50}$ values of 24.08 and $33.00 \mu \mathrm{g} / \mathrm{mL}$, respectively (Radwan et al. 2008).

The 1,8-cineole (72) isolated from leaves of Hyptis martiusii displays significant insecticidal effect against Ae. aegypti larvae at 25 (10\%), $50(53 \%), 100(100 \%) \mathrm{mg} / \mathrm{mL}$ concentrations (Jo et al. 2003). Other monoterpenoids, geranial (73), and neral (74) isolated from Magnolia salicifolia exhibit $100 \%$ mortality with $\mathrm{LD}_{100}$ value of $100 \mathrm{ppm}$ in $24 \mathrm{~h}$ against 4 th instar $A e$. aegypti (Kelm et al. 1997). Cuminaldehyde (75) occurring in plant species, exhibits significant larvicidal and adulticidal toxicity with $\mathrm{LC}_{50}$ values of $38.94 \mathrm{mg} / \mathrm{L}$ in $24 \mathrm{~h}$ against Cx. pipiens larvae (Zahran HE-DM and Abdelgaleil SAM et al. 2010). 
<smiles>Cc1ccc(C(C)C)c(O)c1</smiles>

60<smiles>Cc1cc(O)c(C(C)C)cc1Cl</smiles>

61<smiles>Cc1ccc(C(C)C)cc1O</smiles>

62<smiles>CCCC(C)CCC=C(C)C</smiles>

63<smiles>C=CCc1ccc(O)c(OC)c1</smiles>

64

65<smiles>CNC(=O)c1cc(C)c(Cl)cc1C(C)C</smiles>

66<smiles>CNC(=O)c1cc(C)c(Cl)cc1C(C)C</smiles><smiles>CNC(=O)Oc1cc(C(C)C)ccc1C</smiles><smiles>CNC(=O)OCCC(C)CCC=C(C)C</smiles>

67

68

69<smiles>CNC(=O)OC/C=C(/C)CCC=C(C)C</smiles>

70<smiles>C=C(NC)OC1CC2CCC1(C)C2(C)C</smiles>

71<smiles>CC12CCC(CO1)C2(C)C</smiles>

72<smiles>CC(C)=CCCC(C)=CC=O</smiles>

73<smiles>CC(C)=CCC/C(C)=C\C=O</smiles>

74

\section{Sesquiterpenes}

The $\beta$-selinene (76) isolated from seeds of Apium graveolens shows $100 \%$ mortality against fourth-instar larvae of Ae. aegypti at $50 \mu \mathrm{g} / \mathrm{mL}$ concentrations (Momin et al. 2000). The pregeijerene (77), geijerene (78), and germacrene-D (79) isolated from leaves of Chloroxylon swietenia, possess activity against An. gambiae, Cx. quinquefasciatus and Ae. aegypti. The compound 79 with $\mathrm{LD}_{50}$ values of $1.8,2.1$ and $2.8 \times 10^{-3}$ exerts highest activity followed by 77 $\left(\mathrm{LD}_{50}\right.$ values of 3.0, 3.9 and $\left.5.1 \times 10^{-3}\right)$ while $78\left(\mathrm{LD}_{50}\right.$ values of $4.2,5.4$ and $\left.6.8 \times 10^{-3}\right)$ displays lowest activity against An. gambiae, Cx. quinquefasciatus and Ae. aegypti (Kiran and Devi 2007). The sesquiterpene lactones, $\mathbf{8 0}$ and $\mathbf{8 1}$ isolated from leaves, stem bark, flowers, and fruits of Magnolia salicifolia exhibit significant toxicity against Ae. aegypti larvae. The lactone 80 with $\mathrm{LD}_{100}$ value of $15 \mathrm{ppm}$ kills all the mosquito larvae of Ae. aegypti in $24 \mathrm{~h}$ while 81 exhibits $100 \%$ mortality with $\mathrm{LD}_{100}$ value $>50 \mathrm{ppm}$ in $24 \mathrm{~h}$ (Lee et al. 1971). The sesquiterpene $\mathbf{8 1}$ does not show mosquitocidal activity at $50 \mathrm{ppm}$, thus suggesting the 
presence of a double bond rather than an epoxide at C-4 and C-5 in $\mathbf{8 0}$ is essential for mosquitocidal activity (Kelm et al. 1997). The sesquiterpenes, elemol (82), $\beta$-eudesmol (83), carotol (84), and patchoulol (85) occurring in plants Amyris balsamifera, and Daucus carota, show $>90 \%$ mortality against $C x$. pipiens pallens at $0.1 \mathrm{mg} / \mathrm{mL}$ (Park and Park 2012).<smiles>C=C(C)C1CCC2(C)CCCC(=C)C2C1</smiles><smiles>C/C1=C\CCC/C(C)=C/C=C\CC1</smiles><smiles>C=CC1(C)CCC=CC1C(=C)C</smiles><smiles>C/C=C\CCC/C(C)=C\C(CC)CC</smiles><smiles>C=C1C(=O)OC(C)/C=C(\C)CCC=C2CCC1CC2</smiles><smiles>C=C1C(=O)O[C@H]2[C@H]1CCC1=CCC[C@](C)(O)[C@H]12</smiles>

81<smiles>C=C[C@]1(C)CC[C@@H](C(C)(C)O)C[C@]1(C)C(C)C</smiles>

82<smiles>C=C1CCC[C@]2(C)CCCC[C@@H]12</smiles>

83

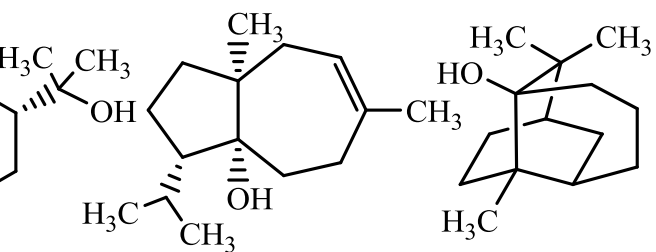

84

85

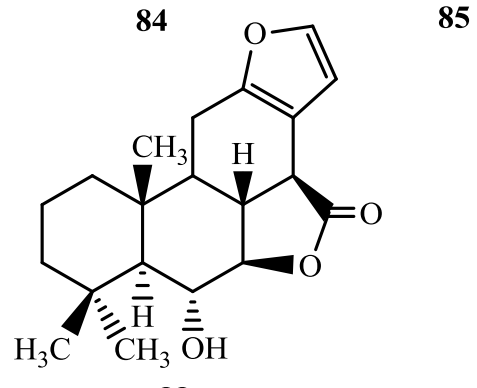

88<smiles>C=C[C@]1(C)CC[C@]2(C)C(CCC3(C)[C@@H]2CC(=O)[C@H](O)C3(C)C)C1</smiles>

91

The guanine type sesquiterpenes, 9-oxoneoprocurcumenol (86), and neoprocurcumenol (87) isolated from Curcuma aromatica, exhibit significant toxicity on mosquito larvae of $C x$. quinquefasciatus (Madhu et al. 2010). Between the two, the compound 86 exerts significant toxicity $(P<0.01)$ on mosquito larvae with $\mathrm{LC}_{50}$ value of $5.81 \mathrm{ppm}$ and $\mathrm{LC}_{90}$ being $9.99 \mathrm{ppm}$ compared to 87 with 13.69 and 23.92 ppm of $\mathrm{LC}_{50}$ and $\mathrm{LC}_{90}$ values, respectively.

\section{Diterpenes}


The diterpenes, 88-90 isolated from Pterodon polygalaeflorus, exhibit significant activity against $4^{\text {th }}$ instar larvae of $A e$. aegypti with $\mathrm{LC}_{50}$ values of $50.08,14.69$ and $21.76 \mu \mathrm{g} / \mathrm{mL}$, respectively (Omena et al. 2006). Likewise, hugorosenone (91) isolated from the Hugonia castaneifolia displays larvicidal effect against An. gambiae larvae with $\mathrm{LC}_{50}$ values of 0.3028 and $0.0986 \mathrm{mg} / \mathrm{mL}$ at 24 and $48 \mathrm{~h}$, respectively (Baraza et al. 2008).

\section{Triterpenes}

The triterpenes, 3 $\beta, 24,25$-trihydroxycycloartane (92) and beddomeilactone (93) isolated from Dysoxylum species (D. malabaricum, D. beddomei etc.) possess strong larvicidal, pupicidal and adulticidal activity. These compounds also affect the reproductive potential of adults by acting as oviposition deterrents. The compound 92 at a concentration of 10 ppm kills more than $90 \%$ of pupae and $85 \%$ of adult mosquitoes. Similarly, compound 93 at the same concentration results in more than $95 \%$ of pupal and larval mortality and $>90 \%$ mortality in case of adult An. stephensi (Nathan et al. 2008)

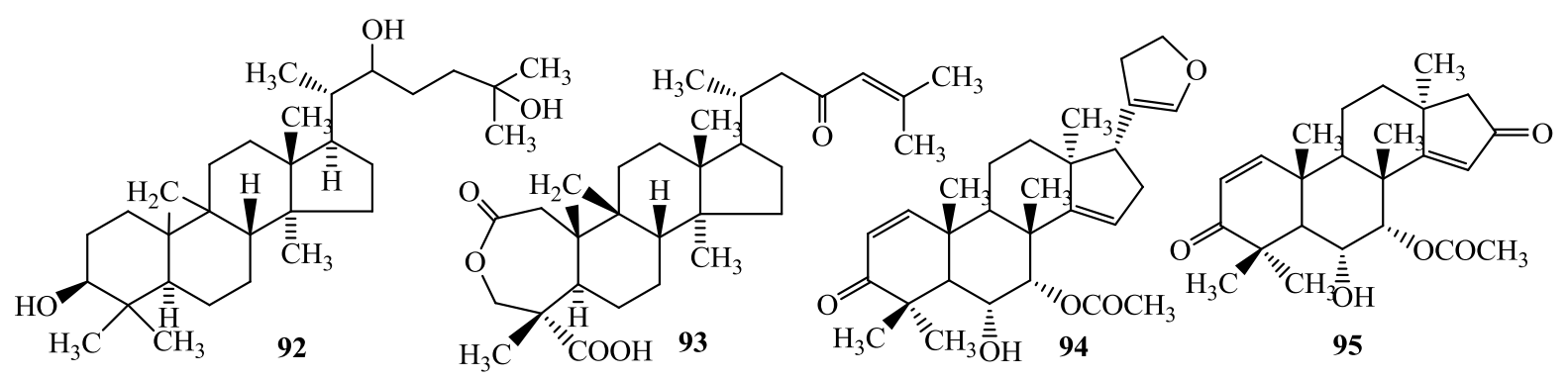

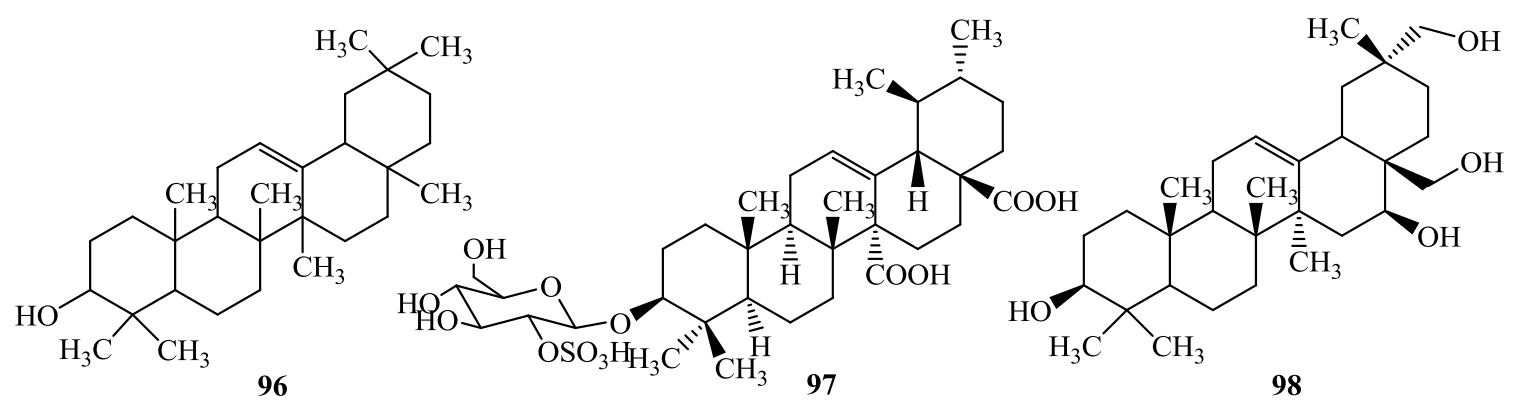

The compounds, 22,23-dihydronimocinol (94) and desfurano-6R-hydroxyazadiradione (95), isolated from leaves of Azadirachta indica, exhibit significant mortality for fourth instar 
larvae of An. stephensi with $\mathrm{LC}_{50}$ values of 60 and 43 ppm, respectively (Siddiqui et al. 2002). The $\beta$-amyrin (96) isolated from stem of Duranta repens display strong activity against first to fourth instars larvae of $C x$. quinquefasciatus with $\mathrm{LC}_{50}$ value of $7.75,16.11$, 28.63 and $26.53 \mathrm{ppm}$, respectively in $24 \mathrm{~h}$ (Nikkon et al. 2010). The ursane-type triterpene saponin 97 isolated from aerial parts of Zygophyllum coccineum, exhibits significant adult mortality of $90 \%$ and $80 \%$ against Ae. aegypti and Cx. quinquefasciatus at 3.1 and $0.5 \mu \mathrm{L}$ concentrations, respectively (Amin et al. 2012). The gymnemagenol (98) isolated from Gymnema sylvestre shows larvicidal against the fourth-instar larvae of An. subpitcus and Cx. quinquefasciatus with $\mathrm{LC}_{50}$ values of $22.99 \mathrm{ppm}$ and $15.92 \mathrm{ppm}$, respectively (Khanna et al. 2011).

\section{Tetranortriterpenoids}

The limonin (99), nomilin (100), and obacunone (101), isolated from the seeds of Citrus reticulate (Champagne et al. 1992), exhibit mosquitocidal activity against fourth instar larvae of Cx. quinquefasciatus at a concentration of 59.57, 26.61 and $6.31 \mathrm{ppm}$, respectively (Jayaprakasha et al. 1997). The limonoids 102-104, isolated from the root bark of Turraea wakefieldii show strong larvicidal activity against late third or early fourth-instar larvae of An. gambiae. In SAR, strong activities of 102, 103, and 104 with $\mathrm{LD}_{50}$ values of 7.83, 7.07, and $7.05 \mathrm{ppm}$, respectively indicate that the epoxidation of the C-14, C-15 double bond or deacetylation of the 11-acetate group does not alter the larvicidal activity (Ndungu et al. 2003).

Other limonoids, azadirachtin (105), salannin (106), deacetylgedunin (107), 17hydroxyazadiradione (108), gedunin (109), and deacetylnimbin (110), isolated from Azadirachta indica possess significant activity against An. stephensi larvae. Among these, the compound 105 with $\mathrm{EC}_{50}$ value of $0.014,0.021,0.028$ and $0.034 \mathrm{ppm}, \mathbf{1 0 6}$ with $\mathrm{EC}_{50}$ value of $0.023,0.036,0.047$ and $0.061 \mathrm{ppm}, \mathbf{1 0 7}$ with $\mathrm{EC}_{50}$ value of $0.028,0.041,0.0614$ and 0.078 ppm, 108 with $\mathrm{EC}_{50}$ value of $0.047,0.054,0.076$ and $0.0104 \mathrm{ppm}, \mathbf{1 0 9}$ with $\mathrm{EC}_{50}$ value of $0.058,0.073,0.095$ and $0.0117 \mathrm{ppm}$ and 110 with $\mathrm{EC}_{50}$ value of $0.055,0.067,0.091$ and 
0.0113 ppm, show activity against first, second, third and fourth instar larvae of $A n$. stephensi, respectively.
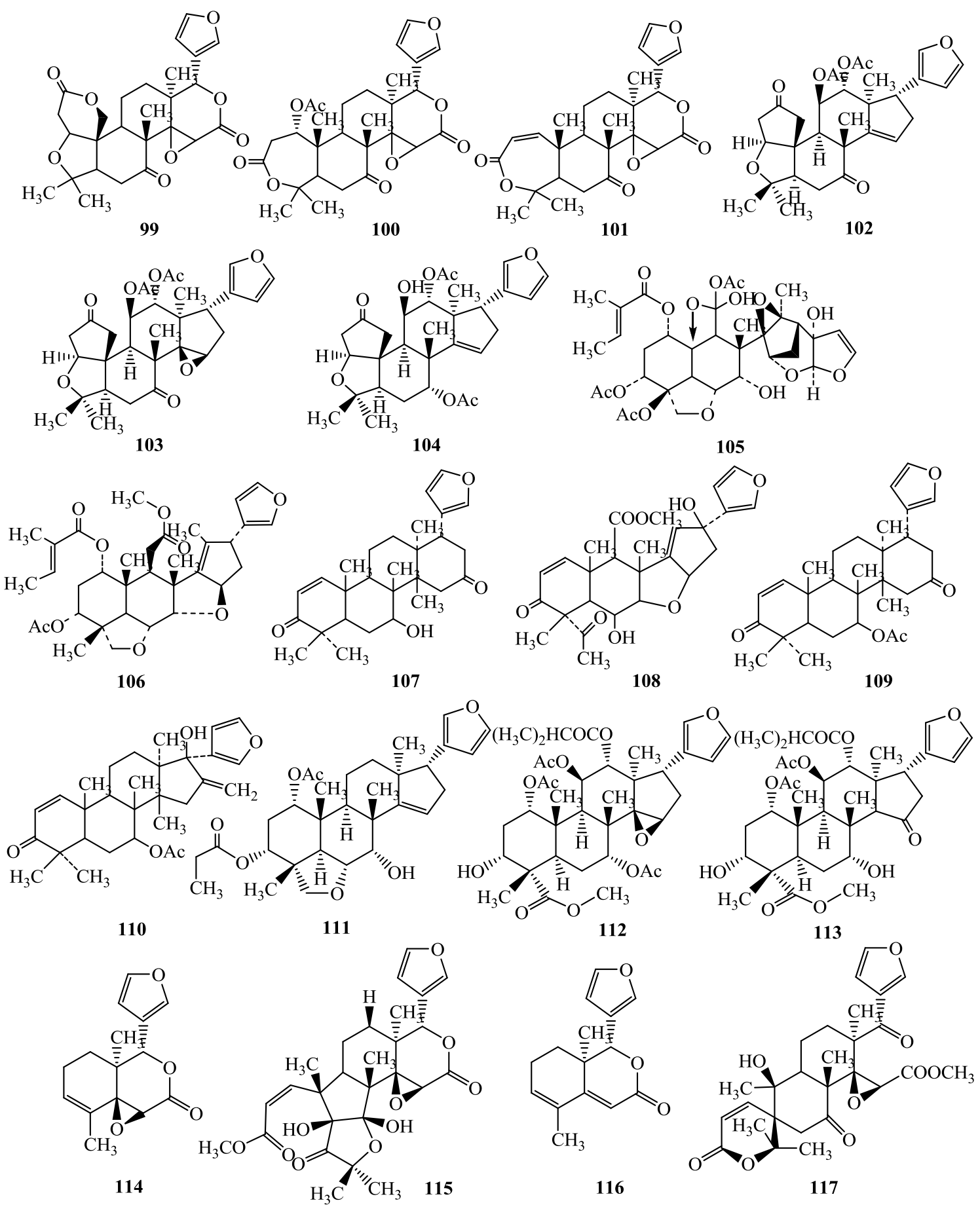

The metabolite 105 exerts $100 \%$ larval mortality at a concentration of $1.0 \mathrm{ppm}$, thus, demonstrates that the use of $A$. indica products may have benefits in mosquito control programs (Nathan et al. 2005). The compounds 111-113 isolated from Turraea species (T. 
wakefieldii, T. floribunda etc.), exhibit toxicity against An. gambiae larvae with $\mathrm{LD}_{50}$ values of 7.1, 4.0, and 3.6 ppm, respectively (Ndungu et al. 2004). Other limonoids calodendrolide (114), harrisonin (115), pedonin (116), and pyroangolensolide (117) isolated from root bark of Harrisonia abyssinica and Calodendrum capense, exhibit toxicity against 2nd instar larvae of Ae. aegypti in the order: $\mathbf{1 1 4}(13.2 \mu \mathrm{m})>\mathbf{1 1 7}(16.6 \mu \mathrm{m})>\mathbf{1 1 5}(28.1 \mu \mathrm{m})>\mathbf{1 1 6}(59.2 \mu \mathrm{m})$. Also, compound 114 results in 100\% mortality at all concentrations, while $\mathbf{1 1 7}$ shows 100\% mortality up to concentration of $50 \mu \mathrm{m}$ (Kiprop et al. 2007).

\section{Steroids}

The compound stigmasterol (118), isolated from Uvariodendron pycnophyllum and many other plant species, exhibit larvicidal activity at different levels with $\mathrm{LC}_{50}$ value of $46 \mathrm{ppm}$ in $24 \mathrm{~h}$ (Kihampa et al. 2010). Likewise, $\beta$-sitosterol-3- $O-\beta$-D-glucoside (119) isolated from Acanthus montanus results in $100 \%$ mortality against adult Ae. aegypti at $1.25 \mu \mathrm{g} / \mathrm{mL}$ concentration (Amin et al. 2012).

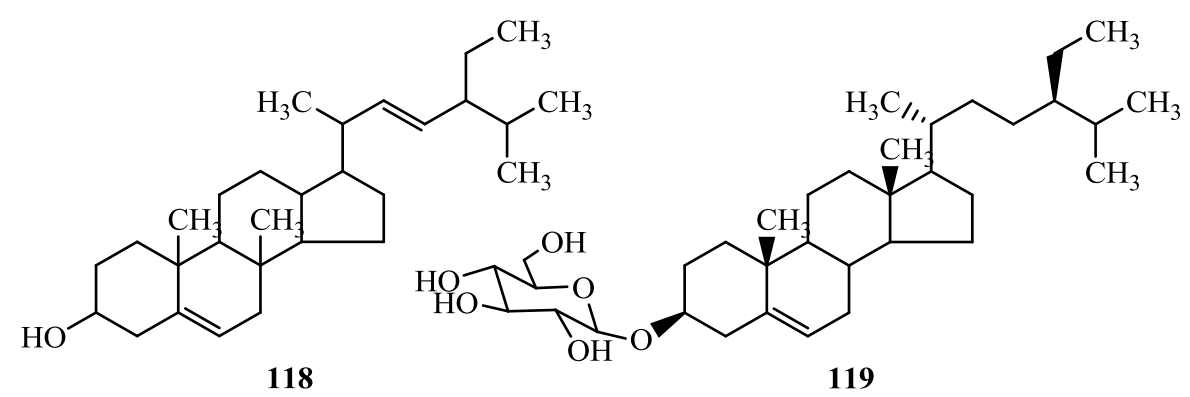

\section{Alkaloids}

\section{Alkamides}

The alkamides, undeca-2E-4Zdien- 8,10-diynoic acid isobutylamide (120), undeca-2Z,4Edien-8,10-diynoic acid isobutylamide (121), dodeca-2E,4Z-dien-8,10-diynoic acid isobutylamide (122), undeca-2E,4Z-dien-8,10-diynoic acid 2-methylbutylamide (123), dodeca-2E,4Z-dien-8,10-diynoic acid 2-ethylbutylamide (124), and a mixture of dodeca$2 E, 4 E, 8 Z, 10 E$-tetraenoic acid isobutylamide (125) and dodeca-2E,4Z,8Z,10Z-tetraenoic acid 
isobutylamide (126) isolated from roots of Echinacea purpurea and other species, display significant activity against $A e$. aegypti larvae. A mixture of compounds $\mathbf{1 2 5}$ and $\mathbf{1 2 6}$, exert most effective mosquitocidal activity at $100 \mu \mathrm{g} / \mathrm{mL}$ concentration with $87.5 \%$ larval mortality in 15 min while $\mathbf{1 2 0}$ display $100 \%$ mortality at same concentration in $2 \mathrm{~h}$.

The alkamides 121 and $\mathbf{1 2 2}$ exhibit $50 \%$ mortality at $100 \mu \mathrm{g} / \mathrm{mL}$ concentration in $9 \mathrm{~h}$ while 123 and 124 show least activity with $10 \%$ mortality at $100 \mu \mathrm{g} / \mathrm{mL}$ concentrations in $24 \mathrm{~h}$ (Clifford et al. 2002). Among isobutyl amides, pellitorine (127), guineensine (128), pipercide (129), and retrofractamide-A (130) isolated from Piper nigrum fruits, exhibit toxicity against Cx. Pipiens larvae in the order: $\mathbf{1 2 9}(0.004 \mathrm{ppm})>\mathbf{1 3 0}(0.028 \mathrm{ppm})>\mathbf{1 2 8}(0.17 \mathrm{ppm})>\mathbf{1 2 7}$ (0.86 ppm). These compounds also possess activity against Ae. aegypti larvae in which $\mathbf{1 3 0}$ exerts pronounced activity at a concentration of $0.039 \mathrm{ppm}$ in compared to compounds $\mathbf{1 2 9}$ (0.1 ppm), $128(0.89 \mathrm{ppm})$ and $127(0.92 \mathrm{ppm})$. The SAR indicates that the $N$-isobutyl amine moiety might play a crucial role in the larvicidal activity, but the methylenedioxyphenyl moiety does not appear essential for toxicity (Park et al. 2002). The compound 131 isolated from Piper longum, exhibits larval toxicity against $C x$. species with $\mathrm{LC}_{50}$ values of 0.58 and 1.88 ppm, respectively (Madhu et al. 2011).
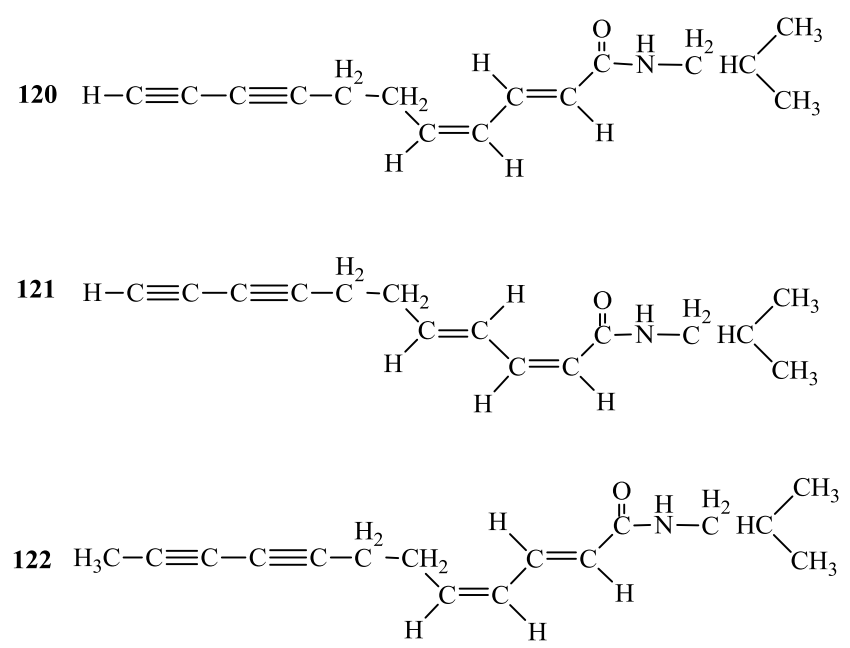


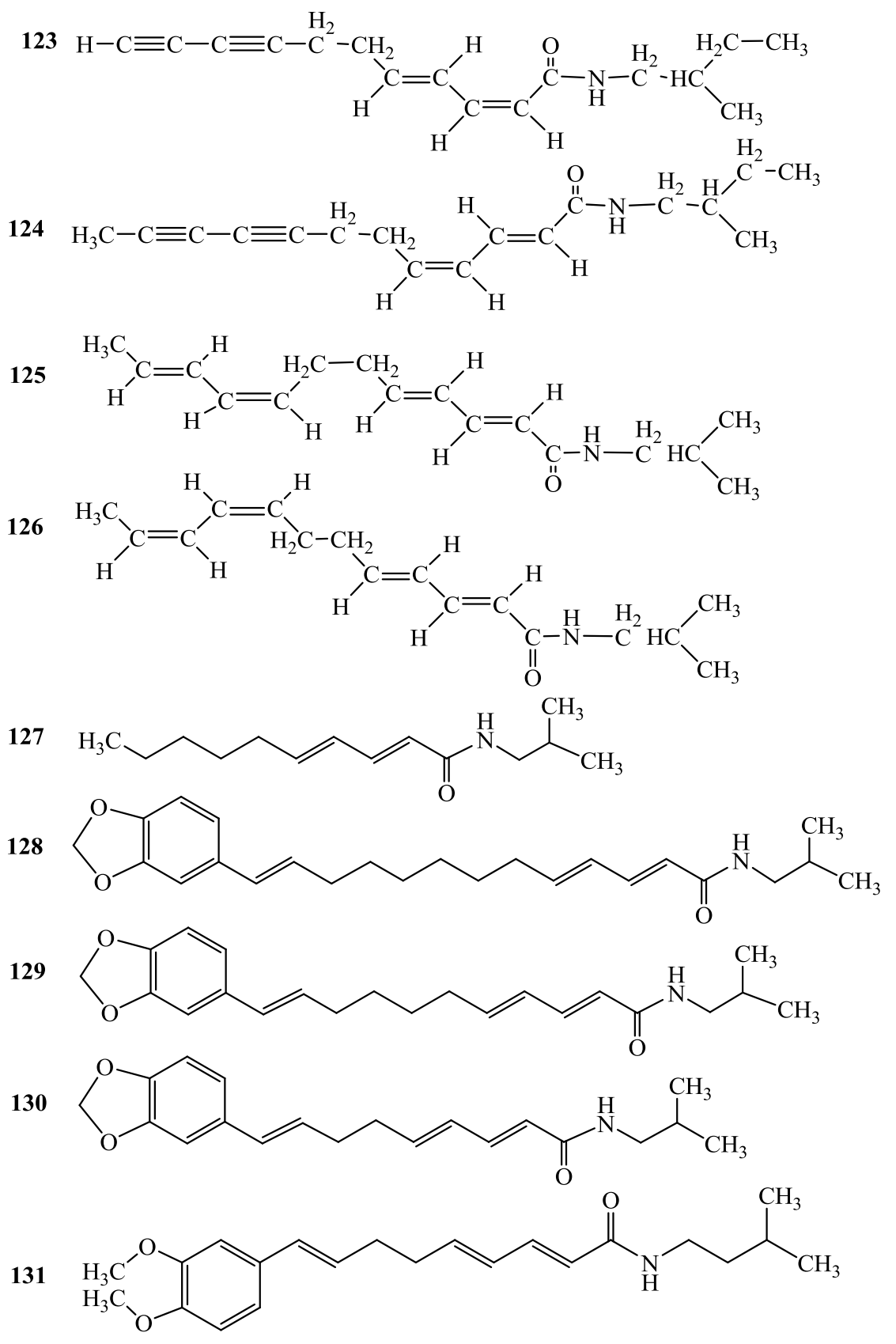

\section{Carbazole alkaloids}

Among carbazoles, mahanimbine (132), murrayanol (133), and mahanine (134) isolated from leaves of Murraya koenigii, display promising mosquitocidal activity against Ae. aegypti (Ramsewak et al. 1999). The alkaloid 132 exhibits $100 \%$ mortality at $100 \mu \mathrm{g} / \mathrm{mL}$ concentration while 133 and 134 at $12.5 \mu \mathrm{g} / \mathrm{mL}$ concentration display $100 \%$ mortality (Nair et al. 1989; Roth et al. 1998). 


\section{Naphthylisoquinoline alkaloid}

The alkaloid, dioncophylline-A (135) isolated from Triphyophyllum peltatum (Bringmann et al. 1990), displays promising activity against different larval stages of An. stephensi with $\mathrm{LD}_{50}$ values of $0.5,1.0$ and $2.0 \mathrm{mg} / \mathrm{L}$ at $3.33,2.66$ and $1.92 \mathrm{~h}$, respectively. In each instar larval stage, the $\mathrm{LC}_{50}$ values decrease as a function of time indicating that $\mathbf{1 3 5}$ continues to exert its action during at least $48 \mathrm{~h}$ (Franqois et al. 1996).<smiles></smiles>

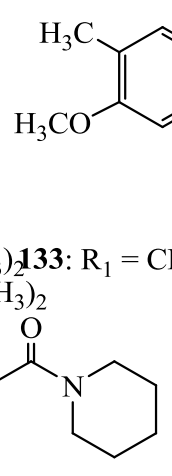

136<smiles>[R19]CCCCCC/C=C\c1ccc2c(c1)OCO2</smiles><smiles>[R]C([R])=CCc1c(O)ccc2c1[nH]c1cc(OC)c(C)cc12</smiles><smiles>COc1cc(C)c(-c2ccc3c(c2O)[C@H](C)NC(C)C3)c2cccc(C)c12</smiles><smiles>CCCC/C=C/C=C/C=C/[C@@H]1CC[C@@H](OC)[C@H](C)N1C</smiles>

\section{Piperidine alkaloids}

The alkaloid, pipernonaline (136) isolated from fruits of Piper longum exhibits activity against the fourth-instar larvae of Ae. aegypti (Yang et al. 2002) and Cx. pipiens (Lee 2000) in $24 \mathrm{~h}$ with $\mathrm{LC}_{50}$ values of 0.25 and $0.21 \mathrm{mg} / \mathrm{L}$, respectively. Similarly, $N$-methyl- $6 \beta$-(decal',3',5'-trienyl)-3- $\beta$--methoxy-2- $\beta$-methylpiperidine (137) isolated from stem bark of Microcos paniculata, shows significant insecticidal activity against second instar larvae of Ae. aegypti with $\mathrm{LC}_{50}$ value of $2.1 \mathrm{ppm}$ at $24 \mathrm{~h}$ (Bandara et al. 2000). Insecticidal activity evaluation of piperidine derivatives 138-170, against female adults of Ae. aegypti following SAR studies using piperine $(E, E)$-1-piperoyl-piperidine as standard insecticide $\left(\mathrm{LD}_{50}\right.$ value of $8.13 \mu \mathrm{g}$ per mosquito) reveal that different moieties (ethyl-, methyl-, and benzyl-) attached to the piperidine ring are responsible for different toxicities (i.e. 138, 1.77; 139, 2.74; 140, 8.76; 141, 1.20; 142, 1.09; 143, 1.13; 144, 4.14; 145, 1.92; 146, 2.07; 147, 1.80; 148, 4.90; 149, 
$4.25 ; 150,2.63 ; 151,6.71 ; 152,1.22 ; 153,1.67 ; 154,0.94 ; 155,1.56 ; 156,1.83 ; 157,0.84 ;$

$158,29.20 ; 159,14.72 ; 160,19.22 ; 161,12.89 ; 162,0.80 ; 163,1.38 ; 164,3.59 ; 165,1.32$

166, 2.07; 167, 7.43; 168, 1.54; 169, 2.72, and 170, $14.72 \mu \mathrm{g})$ against Ae. aegypti.

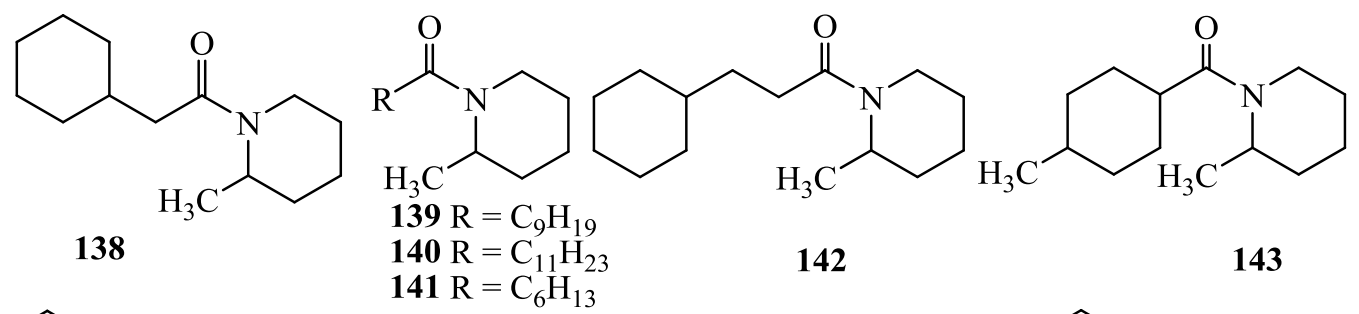

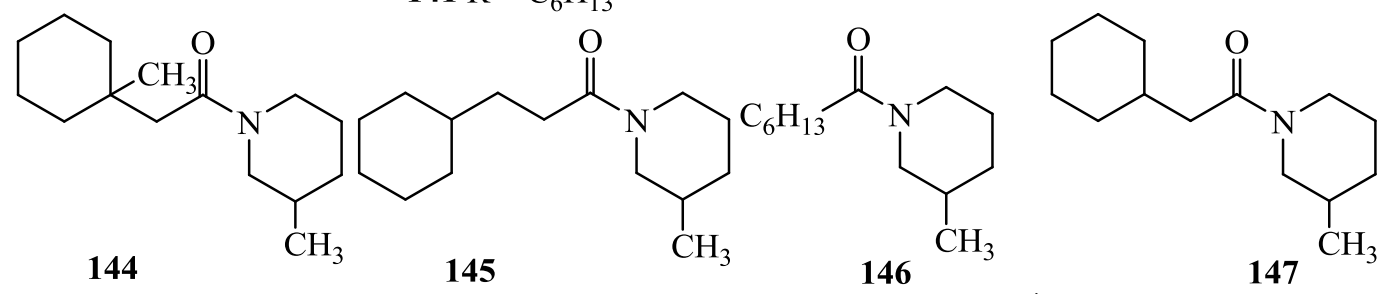<smiles>[R]C(=O)N1CCC(C)C(CCCC(=O)N2CCC(C)CC2)C1</smiles><smiles>CCC1CCCCC1CCC(=O)N1CCCCC1CCC(=O)N1CCCC(CCC(=O)N2CCCCC2CC)C1CC</smiles>

The 3-methylpiperidines 144-147 exhibit slightly lower toxicities than that of 2-methylpiperidines 138-143 with $\mathrm{LD}_{50}$ values ranging from $1.80-4.14 \mu \mathrm{g}$. However, there is no significant difference found between the toxicities of 3-methyl piperidines 144-147 and 4methyl piperidines 148-152, whose $\mathrm{LD}_{50}$ values range from $1.22-6.71 \mu \mathrm{g}$ while the saturated long chain derivatives of 4-methyl-piperidine $148 \& 151$ show lower toxicity compared to others with $\mathrm{LD}_{50}$ values of 4.90 and $6.71 \mu \mathrm{g}$, respectively (Pridgeon et al. 2007). Further, SAR among the piperidines with two different moieties (ethyl- and benzyl-) attached to the carbons of the piperidine ring indicates that 2-ethyl-piperidines 153-157 show higher toxicity than the benzyl-piperidines (158-161) with $\mathrm{LD}_{50}$ values ranging from $0.84-1.83$ and 12.89 - 
$29.20 \mu \mathrm{g}$, respectively. The results of SAR suggest that ethyl-piperidines generally exhibit higher toxicities than methyl-piperidines, followed by benzyl-piperidines whose toxicities are lowest.<smiles>[R]CC1CCCCN1C(=O)CCCCCCCCC=C</smiles><smiles>C=CCCCCCCCCCC(=O)N1CCCC(Cc2ccccc2)C1</smiles><smiles>C=CCCCCCCCCC(=O)N1CCC(C)CC1</smiles><smiles>C=CCCCCCCCCC(=O)N1CCC(Cc2ccccc2)CC1</smiles>

Among 1-undec-10-enoyl-piperidines 159-164 having three different moieties at the second carbon of the piperidine ring, the compound $\mathbf{1 6 2}$ displays highest toxicity with $\mathrm{LD}_{50}$ value of 
$0.80 \mu \mathrm{g}$, compared to $163\left(\mathrm{LD}_{50}\right.$ value of $\left.1.38 \mu \mathrm{g}\right)$ and $164\left(\mathrm{LD}_{50}\right.$ value of $\left.3.59 \mu \mathrm{g}\right)$. Similarly, among compounds $\mathbf{1 6 5 - 1 6 7}$ containing three different moieties attached to the third carbon of the piperidine ring, the compound $\mathbf{1 6 5}$ exhibits highest toxicity ( $\mathrm{LD}_{50}$ value of $1.32 \mu \mathrm{g}$ ), followed by 166 and 167 with $\mathrm{LD}_{50}$ values of 2.07 and $7.43 \mu \mathrm{g}$, respectively. Likewise, among compound 168-170 bearing three different moieties attached to the fourth carbon of the piperidine ring, the compound $\mathbf{1 6 8}$ shows highest toxicity $\left(\mathrm{LD}_{50}\right.$ value of $1.54 \mu \mathrm{g}$ ), following $169\left(\mathrm{LD}_{50}\right.$ value of $\left.2.72 \mu \mathrm{g}\right)$ and $170\left(\mathrm{LD}_{50}\right.$ value of $\left.14.72 \mu \mathrm{g}\right)$.

\section{Stemona alkaloids}

The Stemona alkaloids, stemocurtisine (171), stemocurtisinol (172), and oxyprotostemonine (173) isolated from roots of Stemona curtisii, exhibit potency against mosquito larvae An. minimus with $\mathrm{LC}_{50}$ values of 18, 39, and 4 ppm, respectively. Among these, 173 show highest potency with $\mathrm{LC}_{50}$ value of 4 ppm (Mungkornasawakul et al. 2004).

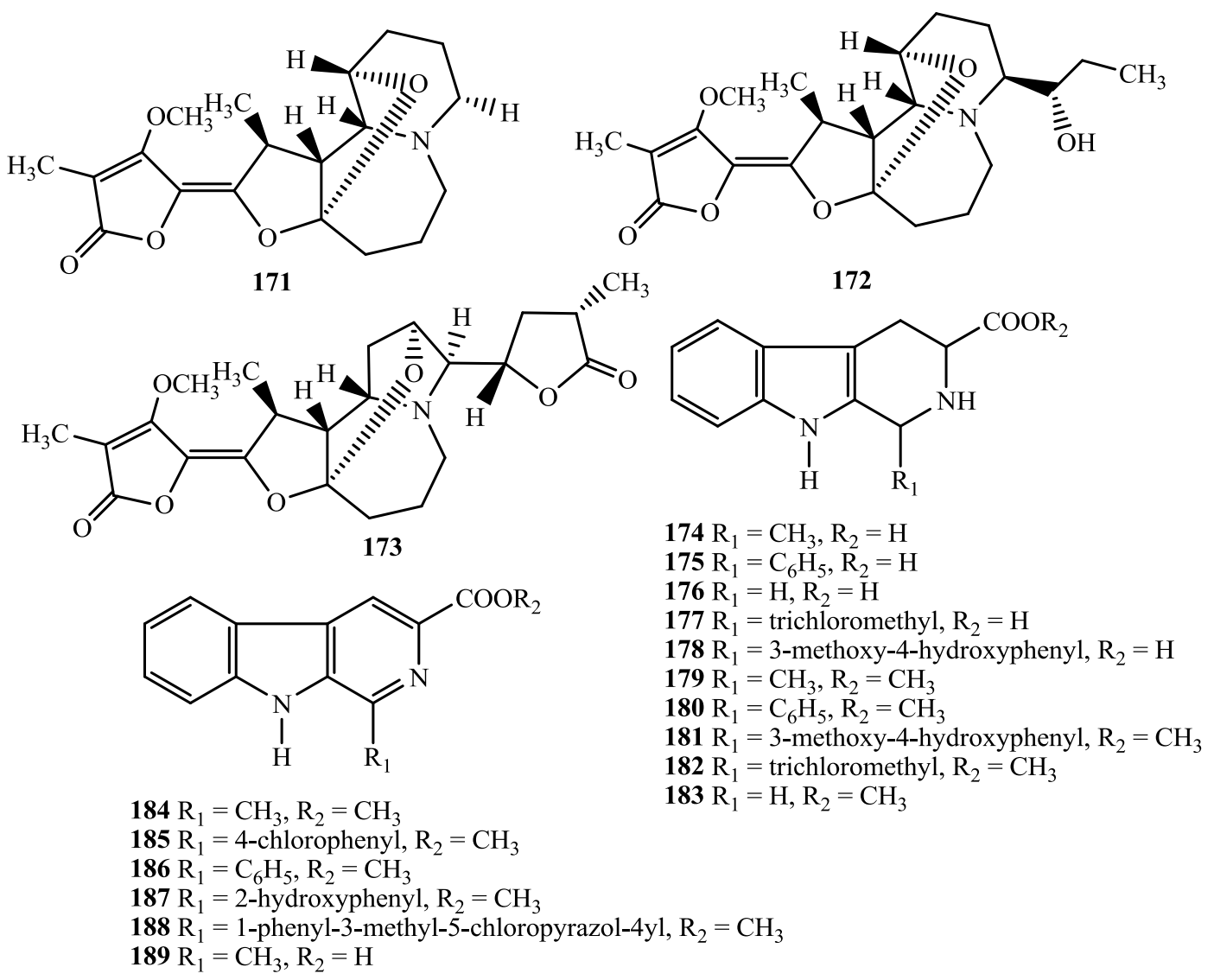




\section{Carboline alkaloids}

The 1,3-substituted $\beta$-carboline derivatives 174-189 related to harmine (a natural insecticide isolated from Peganum harmala), show significant cytotoxicity against fourth instar larvae of Cx. pipiens quinquefasciatus. The results show that compound 1-phenyl-1,2,3,4-tetrahydro- $\beta$ carboline-3-carboxylic acid (175) and methyl 1-phenyl- $\beta$-carboline-3-carboxylate (186) exhibit best larvicidal potential with $\mathrm{LC}_{50 / 90}$ values of 20.82/88.29 and 23.98/295.13 mg/L, respectively after $24 \mathrm{~h}$ of treatment. Other metabolites display $15-40 \%$ mortality at a concentration of $100 \mathrm{mg} / \mathrm{L}$ in $24 \mathrm{~h}$ (Zeng et al. 2010).

\section{Naphthoquinones}

The cordiaquinones, 190-193 isolated from the roots of Cordia curassavica, show toxicity against yellow fever-transmitting Ae. aegypti larvae. The quinones 190 and 192 with 25.0 $\mu \mathrm{g} / \mathrm{mL}$ concentrations result in $100 \%$ larval mortality while 191 and 193 with $12.5 \mu \mathrm{g} / \mathrm{mL}$ concentrations kill all the Ae. aegypti larvae in $24 \mathrm{~h}$ (Ioset et al. 2000). Likewise, the compounds 194-196 isolated from the roots of Cordia linnaei, exhibit larvicidal potency against Ae. aegypti at $12.5,50.0$ and $25.0 \mu \mathrm{g} / \mathrm{mL}$ concentrations, respectively (Ioset et al. 1998). The naphthoquinone, plumbagin (197) isolated from Plumbago zeylanica (Kishore et al. 2010) and other plant species (Mishra et al. 2010a; Mishra et al. 2010b; Mishra and Tiwari 2011) exhibit larvicidal activity against An. gambiae with $\mathrm{LC}_{50}$ value of $1.9 \mu \mathrm{g} / \mathrm{mL}$ (Maniafu et al. 2009; Adikaram et al. 2002). The compound lapachol (198) and its synthetic derivatives (199-201) possess toxicity against fourth instar larvae of Ae. aegypti. The quinone 198 with $\mathrm{LC}_{50}$ value of $15.24 \mu \mathrm{M}$ exerts higher activity in compared to $201(19.45 \mu \mathrm{M}), 199(33.94$ $\mu \mathrm{M})$ and $198(108.7 \mu \mathrm{M})$. Similarly, juglone (202) and its synthetic derivatives (203-211) display significant toxicity against fourth instar larvae of Ae. aegypti. The bromonaphthoquinone 208 with $\mathrm{LC}_{50}$ value of $3.46 \mu \mathrm{M}$ exhibits the best larval toxicity in compared to $205(4.64 \mu \mathrm{M}), 206(3.98 \mu \mathrm{M}), 207(36.48 \mu \mathrm{M}), 208(3.46 \mu \mathrm{M}), 209(24.79 \mu \mathrm{M})$ and 210 
$(21.62 \mu \mathrm{M})$ while 202 and derivatives $\mathbf{2 0 3}, \mathbf{2 0 4}$ and 211 display relatively weak toxicity with $\mathrm{LC}_{50}$ values of 20.61, 21.08, 42.12 and $86.93 \mu \mathrm{M}$, respectively (Ribeiro et al. 2009).

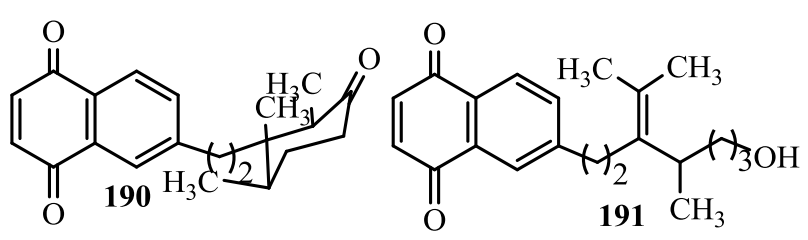<smiles>CC1CC2(C)CC(O2)C(C)(C)C1c1ccc2c(c1)C(=O)C=CC2=O</smiles>

194

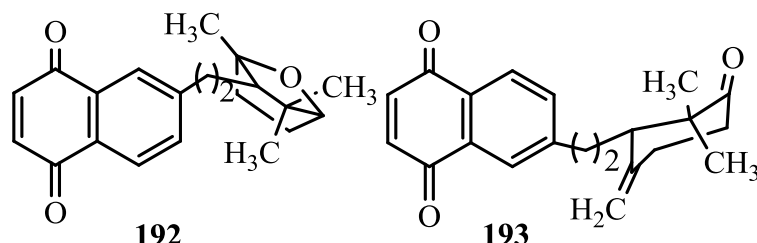

192

193

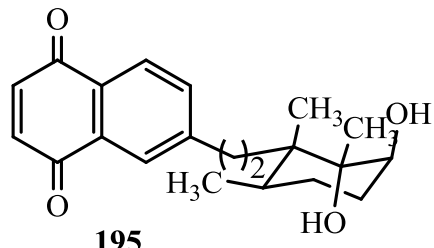

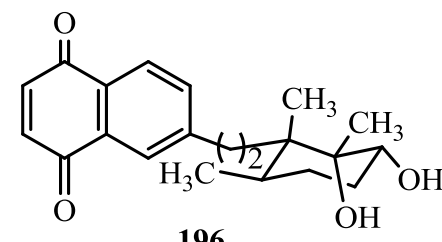

196<smiles>[R]C1=C([R])C(=O)c2c([R3])cccc2C1=O</smiles>

197: $\mathrm{R}_{1}=\mathrm{CH}_{3}, \mathrm{R}_{2}=\mathrm{H}, \mathrm{R}_{3}=\mathrm{OH}$

198: $\mathrm{R}_{1}=\mathrm{OH}, \mathrm{R}_{2}=\mathrm{CH}_{2} \mathrm{CHC}\left(\mathrm{CH}_{3}\right)_{2}, \mathrm{R}_{3}=\mathrm{H}$

199: $\mathrm{R}_{1}=\mathrm{OAc}, \mathrm{R}_{2}=\mathrm{CH}_{2} \mathrm{CHC}\left(\mathrm{CH}_{3}\right)_{2}, \mathrm{R}_{3}=\mathrm{H}$

200: $\mathrm{R}_{1}=\mathrm{OLi}, \mathrm{R}_{2}=\mathrm{CHCHCH}\left(\mathrm{CH}_{3}\right)_{2}, \mathrm{R}_{3}=\mathrm{H}$

201: $\mathrm{R}_{1}=\mathrm{OH}, \mathrm{R}_{2}=\mathrm{CH}_{2} \mathrm{CH}_{2} \mathrm{CH}\left(\mathrm{CH}_{3}\right)_{2}, \mathrm{R}_{3}=\mathrm{H}$

202: $\mathrm{R}_{1}=\mathrm{H}, \mathrm{R}_{2}=\mathrm{H}, \mathrm{R}_{3}=\mathrm{OH}$

203: $\mathrm{R}_{1}=\mathrm{H}, \mathrm{R}_{2}=\mathrm{H}, \mathrm{R}_{3}=\mathrm{OAc}$

204: $\mathrm{R}_{1}=\mathrm{H}, \mathrm{R}_{2}=\mathrm{H}, \mathrm{R}_{3}=\mathrm{OCH}_{3}$

205: $\mathrm{R}_{1}=\mathrm{Br}, \mathrm{R}_{2}=\mathrm{H}, \mathrm{R}_{3}=\mathrm{OH}$

206: $\mathrm{R}_{1}=\mathrm{Br}, \mathrm{R}_{2}=\mathrm{H}, \mathrm{R}_{3}=\mathrm{OAc}$

207: $\mathrm{R}_{1}=\mathrm{Br}, \mathrm{R}_{2}=\mathrm{H}, \mathrm{R}_{3}=\mathrm{OCH}_{3}$

208: $\mathrm{R}_{1}=\mathrm{H}, \mathrm{R}_{2}=\mathrm{Br}, \mathrm{R}_{3}=\mathrm{OH}$

209: $\mathrm{R}_{1}=\mathrm{H}, \mathrm{R}_{2}=\mathrm{Br}, \mathrm{R}_{3}=\mathrm{OAc}$

210: $\mathrm{R}_{1}=\mathrm{H}, \mathrm{R}_{2}=\mathrm{Br}, \mathrm{R}_{3}=\mathrm{OCH}_{3}$

211: $\mathrm{R}_{1}=\mathrm{CH}_{3}, \mathrm{R}_{2}=\mathrm{H}, \mathrm{R}_{3}=\mathrm{H}$

212: $\mathrm{R}_{1}=\mathrm{CH}_{3}, \mathrm{R}_{2}=\mathrm{OCH}_{3}, \mathrm{R}_{3}=\mathrm{OH}$<smiles>C[C@H]1CC(=O)c2c(O)cccc2[C@H]1O</smiles>

213<smiles>[R]C1=CC(=O)c2c(O)ccc(O)c2C1=O</smiles>

14<smiles>CC1=CC(=O)c2c(ccc(O)c2O)[C@@H]1O</smiles>

14
$\mathrm{H}_{3} \mathrm{C}$<smiles>C=C(C(C)=O)c1ccc(O)c2c1C(=O)C(C)=CC2=O</smiles>

Some other naphthoquinones (212-216) isolated from Plumbago capensis, display a varying degrees of mosquitocidal potentials i.e. $\mathrm{LC}_{50}$ value ranging from $1.26-40.66 \mu \mathrm{g} / \mathrm{mL}$ against fourth instar larvae of Ae. aegypti. Among these the compound 213 exhibits strongest activity $\left(\mathrm{IC}_{50}=1.26 \mu \mathrm{g} / \mathrm{mL}\right)$ against larvae of Ae. aegypti (Sreelatha et al. 2010) while compound 212 and 213 exhibit moderate larvicidal activity. The shikonin (217), alkannin (218), and shikalkin (219) isolated from root of Lithospermum erythrorhizon (Chen et al. 2003), Alkanna tinctoria (Urbanek et al. 1996), and young leaves and stems of L. officinale (Haghbeen et al. 2006), display toxicities against mosquito larvae. The quinone 217 at a 
concentration of $3.9 \mathrm{mg} / \mathrm{L}$ show high toxicity against mosquito larvae followed by 219 and 218 at 8.73 and $12.35 \mathrm{mg} / \mathrm{L}$ concentrations, respectively. The SAR studies indicate that the naphthoquinones compared to other natural compounds, are very toxic against mosquito larvae and would be a potential source of natural larvicidal substances (Michaelakis et al. 2009). However, it is difficult to discuss the SAR criteria responsible for the mosquitocidal activities in this set of compounds, presence of reduced quinine ring (ring B), hydroxyl group at C-4 and methyl group at C-3 appears to be important in imparting the mosquitocidal activity compared to others.

\section{Coumarins}

The coumarin, pachyrrhizine (220) isolated from Neorautanenia mitis possess significant activity with $\mathrm{LC}_{50}$ value of $0.007 \mathrm{mg} / \mathrm{mL}$ against adult mosquitoes of An. gambiae. Similary, marmesin (221) isolated from Aegle marmelos exhibits toxicity against An. gambiae adults with $\mathrm{LC}_{50}$ and $\mathrm{LC}_{90}$ values of 0.082 and $0.152 \mathrm{mg} / \mathrm{L}$, respectively (Joseph et al. 2004). Other coumarins 222-234 isolated from Cnidiummon nieri fruit, show insecticidal activity against susceptible $C x$. pipiens pallens and Ae. aegypti larvae. The imperatorin (231) $\left(\mathrm{LC}_{50}=2.88\right.$ $\mathrm{mg} / \mathrm{L}$ ) shows $2.4,4.5$ and 4.6 times more toxicity than isopimpinellin (232), isoimperatorin (233), and osthole (228), respectively. The angelicin (234), psoralen (227), 7-ethoxycoumarin (225), herniarin (224), and xanthotoxin (229) exhibit moderate toxicity with $\mathrm{LC}_{50}$ values ranging from 22.84-39.35 $\mathrm{mg} / \mathrm{L}$. The limettin (226), bergapten (230) and coumarin (222) display moderate toxicity $\left(\mathrm{LC}_{50}=57.03-73.95 \mathrm{mg} / \mathrm{L}\right)$ while umbelliferone (223) exibits lowest toxicity with $\mathrm{LC}_{50}$ value of $132.65 \mathrm{mg} / \mathrm{L}$. The SAR study indicates that the chemical structure, alkoxy substitution, and length of the alkoxyl side chain at C-8 position are essential for imparting toxicity (Wang et al. 2012).

Some other monobromo and tribromo derivatives of 4-methyl-7-hydroxy coumarin (235238), exhibit insecticidal activity $C x$. quinquefasciatus and Ae. aegypti. Among these, compound 3,6,8-tribromo-7-hydroxy-4methyl-chromen-2-one (235) displays most potent 
activity with $\mathrm{LC}_{50}$ value of 1.49 and 2.23 ppm against fourth instar larvae of $C x$. quinquefasciatus and Ae. aegypti, respectively. It shows $100 \%$ larval mortality at a concentration of $25 \mathrm{ppm}$ against Ae. aegypti, and at $10 \mathrm{ppm}$ concentration causes complete lysis of Cx. quinquefasciatus larvae. The 3,6,8-tribromo-4-methyl-2'-oxo-2H-chromen-7-yl acetates $\mathbf{2 3 5}$ and $\mathbf{2 3 6}$ show remarkable ovicidal activity and cause significant reduction of 80$85 \%$ hatching in eggs of Cx. quinquefasciatus and Ae. aegypti at $100 \mathrm{ppm}$ concentrations. The hatched larvae show $100 \%$ mortality in the successive instars. The compounds 3-bromo7-hydroxy-4-methyl-chromen-2-one (237) and 3-bromo-4-methyl-2'-oxo-2H-chromen-7-yl acetate (238), exhibit moderate activity against both mosquito species i.e. at $77.99 \& 89.60$ ppm against $A e$. aegypti, and $46.06 \& 72.65$ ppm concentrations against $C x$. quinquefasciatus (Deshmukh et al. 2008). The 4-hydroxy coumarin derivatives, brodifacoum (239) and cisflocoumafen (240) show strong activity against the $\mathrm{F}_{21}$ laboratory strain of Ae. aegypti with $\mathrm{LC}_{50}$ values of 8.23 and 9.34 ppm, respectively (Jung et al. 2011).<smiles>COc1cc2c(cc1-c1cc3cc4ccoc4cc3oc1=O)OCO2</smiles>

220<smiles>CC(C)(O)C1Cc2cc3ccc(=O)oc3cc2O1</smiles>

221<smiles>[Z]c1cccc(/C=C\CCCCCCC)c1[R]</smiles>

234
229: $\mathrm{R}_{1}=\mathrm{H}, \mathrm{R}_{2}=\mathrm{OCH}_{3}$

230: $\mathrm{R}_{1}=\mathrm{OCH}_{3}, \mathrm{R}_{2}=\mathrm{H}$

231: $\mathrm{R}_{1}=\mathrm{H}, \mathrm{R}_{2}=\mathrm{OCH}_{2} \mathrm{CHC}\left(\mathrm{CH}_{3}\right)_{2}$

232: $\mathrm{R}_{1}=\mathrm{R}_{2}=\mathrm{OCH}_{3}$

233: $\mathrm{R}_{1}=\mathrm{OCH}_{2} \mathrm{CHC}\left(\mathrm{CH}_{3}\right)_{2}, \mathrm{R}_{2}=\mathrm{H}$<smiles>[R]c1cc2c(C)c([R])c(=O)oc2c([R4])c1[R]</smiles>

235: $\mathrm{R} 1=\mathrm{R} 2=\mathrm{R} 4=\mathrm{Br}, \mathrm{R} 3=\mathrm{OH}$

236: $\mathrm{R} 1=\mathrm{R} 2=\mathrm{R} 4=\mathrm{Br}, \mathrm{R} 3=\mathrm{OAc}$

237: $\mathrm{R} 1=\mathrm{Br}, \mathrm{R} 2=\mathrm{R} 4=\mathrm{H}, \mathrm{R} 3=\mathrm{OH}$

238: $\mathrm{R} 1=\mathrm{Br}, \mathrm{R} 2=\mathrm{R} 4=\mathrm{H}, \mathrm{R} 3=\mathrm{OAc}$<smiles>O=c1oc2ccccc2c(O)c1C1CCC(c2ccc(-c3ccc(Br)cc3)cc2)c2ccccc21</smiles>

$\mathrm{R}_{2}$<smiles>[R]C=C</smiles>

222: $\mathrm{R}_{1}=\mathrm{H}, \mathrm{R}_{2}=\mathrm{H}$

223: $\mathrm{R}_{1}=\mathrm{H}, \mathrm{R}_{2}=\mathrm{OH}$

224: $\mathrm{R}_{1}=\mathrm{H}, \mathrm{R}_{2}=\mathrm{OCH}_{3}$

225: $\mathrm{R}_{1}=\mathrm{H}, \mathrm{R}_{2}=\mathrm{OC}_{2} \mathrm{H}_{5}$

226: $\mathrm{R}_{1}=\mathrm{R}_{2}=\mathrm{OCH}_{3}$

228: $\mathrm{R}_{1}=\mathrm{H}, \mathrm{R}_{2}=\mathrm{OCH}_{3}, \mathrm{R}_{3}=\mathrm{CH}_{2} \mathrm{CHC}\left(\mathrm{CH}_{3}\right)_{2}$

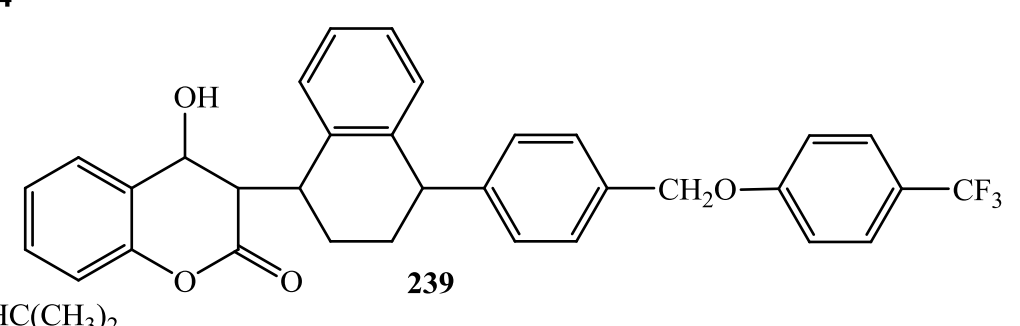




\section{Phenylpropanoid}

The phenylpropanoid dillapiol (241) isolated from leaves of Piper aduncum and its semisynthetic derivatives 242-254, show lethality against adults of female Ae. aegypti. The metabolites $\mathbf{2 4 1}$ and $\mathbf{2 4 2}$ exhibit $100 \%$ mortality at $0.57 \mu \mathrm{g} / \mathrm{cm}^{2}$ surface density after $45 \mathrm{~min}$. The compounds 243-246 exert 80\% 98\% lethalities against female adults of Ae. aegypti after 90 min. Additionally, dillapiol oxide (248) kills about 51\% and acetonide 250 kills $29 \%$ of mosquitoes after 90 min of exposure. Other dillapiols 251-254 possess low mortality (4-11\%) against these mosquito species. The SAR study suggests that C-3 side chain is important for the toxic effects of these substances against $A$. aegypti adult females. The compounds isodillapiol (242), methyl ether (243), propyl ether (245), and butyl ether (246) exhibit greater mosquitocidal potential than 241, and their activities fall in order: $242>246>243>245>$ 241 (Pinto et al. 2012).<smiles>C=CCc1cc2c(c(OC)c1OC)OCO2</smiles>

241<smiles>CCOC(C)Cc1cc2c(c(OC)c1OC)OCO2</smiles>

243: $\mathrm{n}=0$

244: $\mathrm{n}=1$

245: $\mathrm{n}=2$

246: $\mathrm{n}=3$

247: $\mathrm{n}=7$<smiles>C/C=C/c1cc2c(c(OC)c1OC)OCO2</smiles>

242<smiles>COc1c(CC2CO2)cc2c(c1OC)OCO2</smiles>

248<smiles>COc1cc(C2COc3cc4occc4cc3C2=O)cc(OC)c1OC</smiles><smiles>COc1cc2c(cc1C1COc3cc4occc4cc3C1=O)OCO2</smiles>

255<smiles>[R20]CC([R10])Cc1cc2c(c(OC)c1OC)OCO2</smiles>

$249 \mathrm{R}_{1}=\mathrm{R}_{2}=\mathrm{H}$, $250 \mathrm{R}_{1}, \mathrm{R}_{2}=>\mathrm{C}\left(\mathrm{CH}_{3}\right)_{2}$ $\mathbf{2 5 1}=\mathrm{R}_{1}=\mathrm{COCH}_{3}, \mathrm{R}_{2}=\mathrm{COCH}_{3}$ $252=\mathrm{R}_{1}, \mathrm{R}_{2}=>\mathrm{C}=\mathrm{O}$, $253 \mathrm{R}_{1}=\mathrm{H}, \mathrm{R}_{2}=\mathrm{CH}_{2} \mathrm{C}_{6} \mathrm{H}_{5}$ $\mathbf{2 5 4}=\mathrm{R}_{1}=\mathrm{H}, \mathrm{R}_{2}=\mathrm{COCH}_{3}$

\section{Flavonoids and isoflavonoids}

The isoflavonoids, neotenone (255), and neorautanone (256) isolated from Neorautanenia mitis, display activity against adults of An. gambiae with $\mathrm{LD}_{50}$ values of 0.008 and 0.009 
$\mathrm{mg} / \mathrm{mL}$, respectively (Puyvelde et al. 1987). The flavonoids, poncirin (257), rhoifolin (258) and naringin (259) isolated from Poncirus trifoliata, show larvicidal activity against $A e$. aegypti with $\mathrm{LC}_{50}$ values of $0.082-0.122 \mathrm{mg} / \mathrm{L}$ and $\mathrm{LC}_{90}$ values $0.152-0.223 \mathrm{mg} / \mathrm{L}$ after $24 \mathrm{~h}$ (Rajkumar and Jebanesan 2008). Other flavonoids, linaroside (260), homoplantagenin (261), 5,7,3'-trihydroxy-6,4'-dimethoxy flavone-7-O-glucoside (262) isolated from Acanthus montanus exhibit mosquitocidal activity against adult Ae. aegypti at a concentration 1.25 $\mu \mathrm{g} / \mathrm{mL}$ (Amin et al. 2012).

\section{Pterocarpans}

The pterocarpans, neoduline (263), 4-methoxyneoduline (264), and nepseudin (265) isolated from tubers of Neorautanenia mitis, exhibit mosquitocidal activity against An. gambiae and Cx. quinquefaciatus larvae with $\mathrm{LD}_{50}$ values $0.005,0.011$ and $0.003 \mathrm{mg} / \mathrm{mL}$, respectively (Joseph et al. 2004; Breytenbach and Rall 1980).

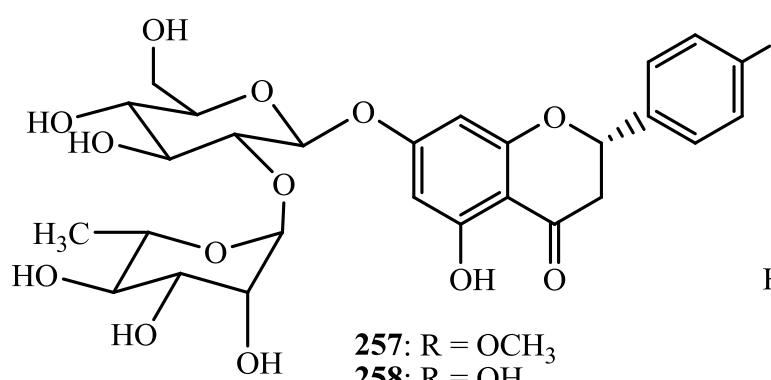

258: $\mathrm{R}=\mathrm{OH}$

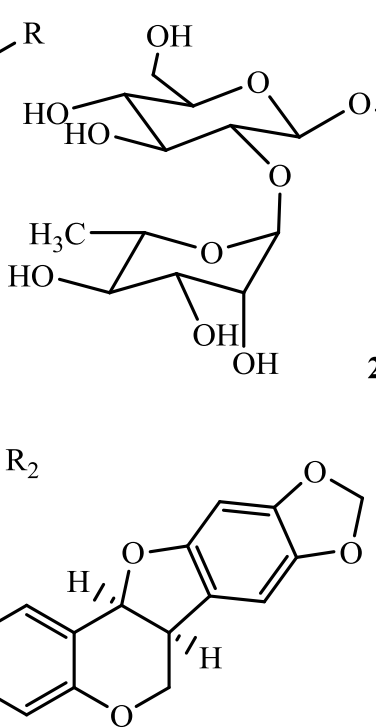

263<smiles>O=C1C[C@H](c2ccc(O)cc2)Oc2cccc(O)c21</smiles>

259<smiles>COc1c2c(cc3ccoc13)C1Oc3cc4c(cc3C1CO2)OCO4</smiles>

260: $\mathrm{R}_{1}=\mathrm{H}, \mathrm{R}_{2}=\mathrm{OCH}_{3}$

261: $\mathrm{RI}=\mathrm{H}, \mathrm{R}_{2}=\mathrm{OH}$

264<smiles>COc1ccc2c(c1OC)OCC1c3cc4c(cc3OC21)OCO4</smiles><smiles>[R2]Oc1cc(/C=C/C(=O)CC(=O)/C=C/c2ccc(O)c([R20])c2)ccc1O</smiles> 


\section{Curcuminoid and phenolic acid}

The curcumin (266) isolated from Curcuma longa and its synthetic derivative di-Odemethylcurcumin (267), show significant larvicidal activity against $C x$. pipiens with $\mathrm{LC}_{50}$ value of 19.07 and $12.42 \mathrm{mg} / \mathrm{L}$, respectively (Sagnou et al. 2012). However, based on the $\mathrm{LC}_{90}$ values, compound 267 shows greater activity $\left(\mathrm{LC}_{90}=29.40 \mathrm{mg} / \mathrm{L}\right)$ than $266\left(\mathrm{LC}_{90}=\right.$ $61.63 \mathrm{mg} / \mathrm{L}$ ). Other curcumin analogs 268-270 exhibit larvicidal activities against fourth instar larvae Ae. aegypti with $\mathrm{LC}_{50}$ values ranging from 17.29-27.90 $\mu \mathrm{M}$ (Anstrom et al. 2012).<smiles>O=C1/C(=C/c2ccco2)CCC/C1=C\c1ccco1</smiles>

269<smiles>CCCCCC(C)=O</smiles>

268<smiles>CCC[C@H](O)CC(=O)CCc1ccc(O)c(OC)c1</smiles><smiles>O=C(/C=C/c1ccccc1O)/C=C/c1ccccc1C(F)(F)F</smiles>

270<smiles>O=C(O)C1=C[C@H](O)[C@H](O)[C@H](O)C1</smiles>

271<smiles>O=C(O)c1ccc(O)c(O)c1</smiles>

275

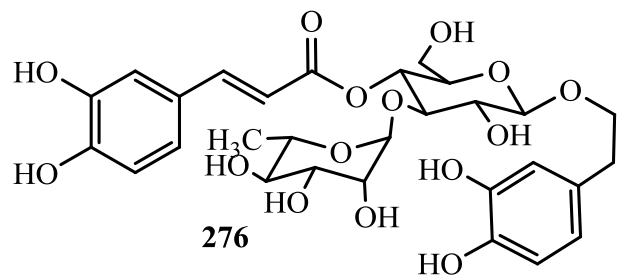

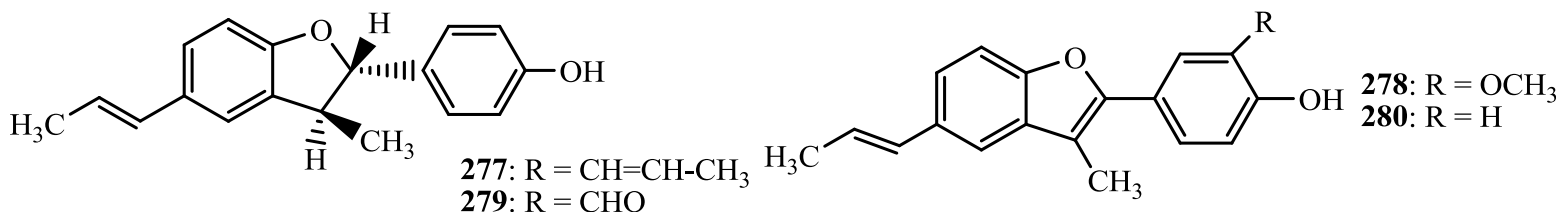

The zingiber metabolites, 4-gingerol (271), 6-dehydrogingerdione (272), and 6dihydrogingerdione (273) isolated from rhizomes of Zingiber officinale, exhibit larvicidal activities against fourth instar larvae of $A$ e. aegypti with $\mathrm{LC}_{50}$ values of $4.25,9.80$, and 18.20 ppm, respectively. These metabolites also display larvicidal activity against $C x$. 
quinquefasciatus with $\mathrm{LC}_{50}$ values of 5.52 (271), 7.66 (272), 27.24 (273) ppm (Rahuman et al. 2008). The shikimic acid (271), protochatecuic acid (272), and acetoside (273) isolated from Acanthus montanus, show $40 \%$ mosquitocidal activity against Ae. aegypti adult at a concentration $1.25 \mu \mathrm{g} / \mathrm{mL}$ while 273 exhibit $70 \%$ mosquitocidal activity at a concentration $1.25 \mu \mathrm{g} / \mathrm{mL}$ (Amin et al. 2012).

\section{Lignans}

The lignans, conocarpan (277), eupomatenoid-5 (278), eupomatenoid-6 (279), and decurrenal (280) isolated from Piper decurrens possess significant mortality at $10 \mu \mathrm{g} / \mathrm{mL}$ concentrations against mosquito larvae (Chauret et al. 1996). Similarly, compound leptostachyol acetate (281) and 8'-acetoxy-2,2',6-trimethoxy-3,4,4',5'-dimethylenedioxyphenyl-7,7'-dioxabicyclo[3.3.0]octane (282) isolated from the roots of Phryma leptostachya asiatica, exhibit insecticidal activity against third instar larvae of $C x$. pipiens pallens, Ae. aegypti and Ochlerotatus togoi. Among these, compound 282 shows relatively weak insecticidal activity while compound 281 with $\mathrm{LC}_{50}$ values of $0.41,2.1$, and $2.3 \mathrm{ppm}$ exhibits strong activity against Cx. pipiens pallens, Ae. aegypti, and $O$. togoi, respectively (Park et al. 2005).

Other lignans i.e. phrymarolin-I (283), haedoxane-A (284), and haedoxane-E (285) isolated from Phryma leptostachya, show high larvicidal activity against fourth instar larvae of $C x$. pipiens pallens at $24 \mathrm{~h}$ with $\mathrm{LC}_{50}$ values of $1.21,0.025$, and $0.15 \mathrm{ppm}$, and $\mathrm{LC}_{90}$ values of 5.03, 0.085 and 0.37 ppm, respectively (Xiao et al. 2012).

\section{Rotenoids}

The compounds deguelin (286), 12a-hydroxy- $\alpha$-toxicarol (287), tephrosin (288), $\alpha$-toxicarol (289), and 6a, 12a-dehydro- $\alpha$-toxicarol (290) isolated from roots of Tephrosia toxicaria, show larvicidal activity against Ae. aegypti with $\mathrm{LC}_{50}$ of $3.38 \pm 2.02,3.22 \pm 1.37,6.31 \pm 0.69$ and $24.55 \pm 0.13$ ppm, respectively. The metabolite 290 displays weaker activity than $\mathbf{2 8 6}$ 289 with $\mathrm{LC}_{50}>50 \mathrm{ppm}$. The SAR study indicates that the presence or absence of the double 
bond between C-6a and C-12a is responsible for difference in toxicity (Nunes e Vasconcelos et al. 2012).<smiles>COc1cc2c(cc1C1OC[C@H](c3c(OC)cc4c(c3OC)OCO4)[C@H]1OC(C)=O)OCC2(OC(C)=O)c1cc2c(cc1OC)OCO2</smiles><smiles>CCCOC1(Oc2cc3c(cc2OC)OCO3)COCC1c1cc2c(cc1OC)OCO2</smiles>

283

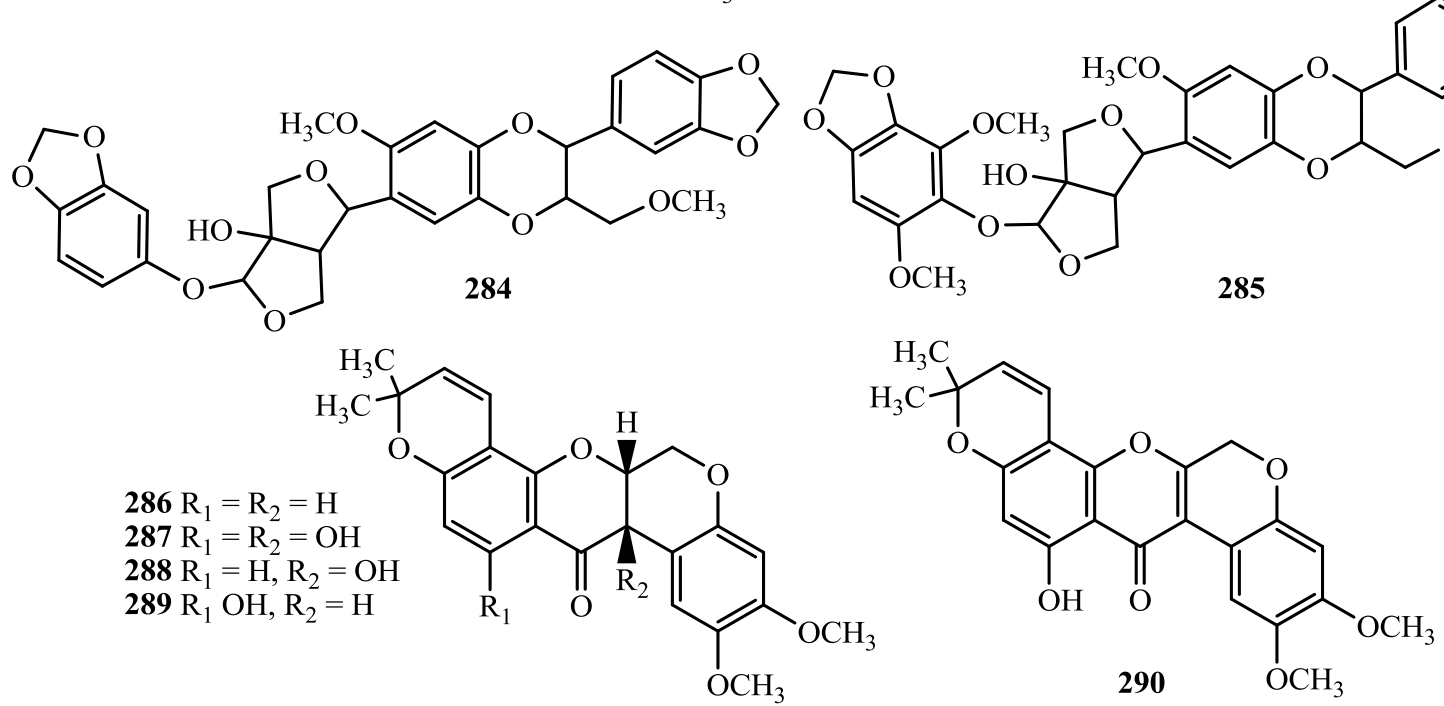

\section{Mosquitocides from microorgainsms}

An algal metabolite caulerpin (291), isolated from Caulerpa racemosa, shows larvicidal activity against second, third and fourth instar larvae of $C x$. pipiens mosquito with $\mathrm{LC}_{50}$ of 1.42, 1.81, 1.99 ppm, respectively. Likewise, caulerpinic acid (292) isolated from same plant species, exhibits activity with $\mathrm{LC}_{50}$ of $3.04,3.90$, and $4.89 \mathrm{ppm}$ against second, third and fourth instar larvae, respectively (Alarif et al. 2010).

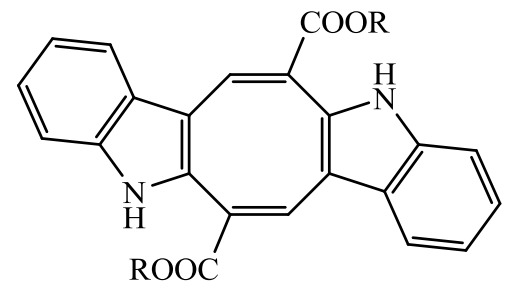

$291 \mathrm{R}=\mathrm{CH}_{3}, 292 \mathrm{R}=\mathrm{H}$ 


\section{Conclusive remarks}

Our ancestors exclusively depended on the use of plant-derived products to repel or kill mosquitoes and other blood-sucking insects. Modern synthetic chemicals could provide immediate results for the control of insects/mosquitoes; on the contrary they bring irreversible environmental hazard, severe side effects and pernicious toxicity to human being and beneficial organisms. In concern to the quality and safety of life and the environment, the emphasis on controlling mosquito vectors has shifted steadily from the use of conventional chemicals toward alternative insecticides that are target-specific, biodegradable, and environmentally safe, and these are generally botanicals in origin. Therefore, right now use of eco-friendly and cost-free plant based products for the control of insects/mosquitoes is inevitable. Efforts should be made to promote the use of easy accessible and affordable traditional insect/mosquito repellent plants.

\section{Acknowledgement}

The authors sincerely acknowledge the department of plant science, University of Pretoria, South Africa and National Research Foundation for support this work.

\section{References}

Adikaram NKB, Karunaratne V, Bandare BMR, Hewage CM, Abayasekara C, Mendis BSS (2002) Antifungal properties of Plumbagin. J Natn Sci Foundation Sri Lanka 30:89-95

Alarif WM, Abou-Elnaga ZS, Ayyad S-EN, Al-lihaibi SS (2010) Insecticidal metabolites from the green alga Caulerpa racemosa. CLEAN-Soil, Air, Water 38:548-557

Albuquerque MRJR, Silveira ER, Uchoa DEDA, Lemos TLG, Souza EB, Santiago GMP, Pessoa ODL (2004) Chemical composition and larvicidal activity of the essential oils from Eupatorium betonicaeforme (D.C.) Baker (Asteraceae). J Agric Food Chem $52: 6708-6711$ 
Al-Doghairi M, El-Nadi A, El-hag E, Al-Ayedh H (2004) Effect of Solenostemma argel on oviposition, egg hatchability and viability of Culex pipiens L larvae. Phytother Res $18: 335-338$

Al-Sharook Z, Balan K, Jiang Y, Rembold H (1991) Insect growth inhibitors from two tropical meliaceae, effects of crude seed extracts on mosquito larvae. J Appl Entomol 111:425430

Amin E, El-Hawary SS, Fathy MM, Mohammed R, Ali Z, Tabanca N, Wedge DE, Becnel JJ, Khan IA (2011) Triterpenoidal saponins: Bioactive secondary metabolites from Zygophyllum coccineum. Planta Medica 77:488-491

Amin E, Radwan MM, El-Hawary SS, Fathy MM, Mohammed R, Becnel JJ, Khan I (2012) Potent insecticidal secondary metabolites from the medicinal plant Acanthus montanus. Rec Nat Prod 6:301-305

Anees AM (2008) Larvicidal activity of Ocimum sanctum Linn. (Labiatae) against Aedes aegypti (L.) and Culex quinquefasciatus (Say). Parasitol Res 101:1451-1453

Anstrom DM, Zhou X, Kalk CN, Song B, Lan Q (2012) Mosquitocidal properties of natural product compounds isolated from Chinese herbs and synthetic analogs of Curcumin. $\mathrm{J}$ Med Entomol 49:350-355

Bagavan A, Kamaraj C, Rahuman A, Elango G, Zahir AA, Pandiyan G (2009) Evaluation of larvicidal and nymphicidal potential of plant extracts against Anopheles subpictus Grassi, Culex tritaeniorhynchus Giles and Aphis gossypii Glover. Parasitol Res 104:1109-1117

Balandrin M, Klocke J, Wurtele ES, Bollinger WH (1985) Natural plant chemicals: Sources of industrial and medicinal materials. Science 228:1154-1160

Bandara KANP, Kumar V, Jacobsson U, Molleyres LP (2000) Insecticidal piperidine alkaloid from Microcos paniculata stem bark. Phytochemistry 54:29-32 
Baraza LD, Joseph CC, Munissi JJE, Nkunya MHH, Arnold N, Porzel A, Wessjohann L (2008) Antifungal rosane diterpenes and other constituents of Hugonia castaneifolia. Phytochemistry 69:200-205

Boulogne I, Petit P, Ozier-Lafontaine H, Desfontaines L, Loranger-Merciris G (2012) Insecticidal and antifungal chemicals produced by plants: a review. Environ Chem Lett DOI $\underline{10.1007 / \mathrm{s} 10311-012-0359-1}$

Breytenbach JC, Rall GJH (1980) Structure and synthesis of isoflavonoid analogues from Neorautanenia amboensis Schinz. J Chem Soc Perkin I:1804

Bringmann G, Rfibenacker M, Jansen JR, Scheutzow D (1990) On the structure of the dioncophyllaceae alkaloids dioncophylline a ("triphyophylline") and "O-MethylTriphyophylline. Tetrahedron Lett 31:639-642

Chaithong U, Choochote W, Kamsuk K, Jitpakdi A, Tippawangkosol P, Chaiyasit D, Champakaew D, Tuetun B, Pitasawat B (2006) Larvicidal effect of pepper plants on Aedes aegypti (L.) (Diptera: Culicidae). J Vector Ecol 31:138-144

Champagne DE, Koul O, Isman MB, Scudder GGE, Towers GHN (1992) Biological activity of limonoids from the rutales. Phytochemistry 31:377-394

Chauret DC, Bernard CB, Arnason JT, Durst T (1996) Insecticidal neolignans from Piper decurrens. J Nat Prod 59:152-155

Chen X, Yang L, Zhang N, Turpin JA, Buckheit RW, Osterling C, Oppenheim JJ, Howard OMZ (2003) Shikonin, a component of chinese herbal medicine, inhibits chemokine receptor function and suppresses human immunodeficiency virus type 1. Antimicrob Agents Chemother 47:2810-2816

Cheng SS, Huang CG, Chen YJ, Yu JJ, Chen WJ, Chang ST (2009) Chemical compositions and larvicidal activities of leaf essential oils from two eucalyptus species. Biores Technol 100:452-456 
Cheng SS, Liu JY, Tsai KH, Chen WJ, Chang ST (2004) Chemical composition and mosquito larvicidal activity of essential oils from leaves of different Cinnamomum osmophloeum provenances. J Agric Food Chem 52:4395-4400

Choochate W, Chaiyasit D, Kanjanapothi D, Rattanachanpichai E, Jitpakdi A, Tuetun B, Pitasawat B (2005) Chemical composition and antimosquito potential of rhizome extract and volatile oil derived from Curcuma aromatica against Aedes aegypti (Diptera: Culicidae). J Vector Ecol 30:302-309

Chowdhury N, Chatterjee SK, Laskar S, Chandra G (2009) Larvicidal activity of Solanum villosum Mill (Solanaceae: Solanales) leaves to Anopheles subpictus Grassi (Diptera: Culicidae) with effect on non-target Chironomus circumdatus Kieffer (Diptera: Chironomidae). J Pest Sci 82:13-18

Chowdhury N, Ghosh A, Chandra G (2008) Mosquito larvicidal activities of Solanum villosum berry extract against the Dengue vector Stegomyia aegypti. BMC Comple Alter Med 8:10

Chowdhury N, Laskar S, Chandra G (2008) Mosquito larvicidal and antimicrobial activity of protein of Solanum villosum leaves. BMC Comple Alter Med 8:62

Ciccia G, Coussio J, Mongelli E (2000) Insecticidal activity against Aedes aegypti larvae of some medicinal South American plants. J Ethnopharmacol 72:185-189

Clifford LJ, Nair MG, Rana J, Dewitt DL (2002) Bioactivity of alkamides isolated from Echinacea purpurea (L.) Moench. Phytomedicine 9:249-253

Das NG, Goswami D, Rabha B (2007) Preliminary evaluation of mosquito larvicidal efficacy of plant extracts. J Vect Borne Dis 44: 145-148

David JP, Rey D, Pautou MP, Meyran JC (2000) Differential toxicity of leaf litter to dipteran larvae of mosquito developmental sites. J Invertebr Pathol 75:9-18 
Deshmukh M, Pawar P, Joseph M, Phalgune U, Kashalkar R, Deshpande NR (2008) Efficacy of 4-methyl-7-hydroxy coumarin derivatives against vectors Aedes aegypti and Culex quinquefasciatus. Indian J Experimen Biol 46:788-792

Dorni AIC, Vidyalakshmi KS, Vasanthi RH, Rajamanickam GV, Dubey GP (2007) HPTLC method for the quantification of plumbagin in three Plumbago species. Res $\mathrm{J}$ Phytochem 1:46-51

Eckenbach U, Lampman RL, Seigler DS, Ebinger J, Novak RJ (1999) Mosquitocidal activity of acetylenic compounds from Cryptotaenia Canadensis. J Chem Ecol 25:1885-1893

Erler F, Ulug I, Yalcinkaya B (2006) Repellent activity of five essential oils against Culex pipiens. Fitoterapia 77:491-494

Evans DA, Raj RK (1991) Larvicidal efficacy of Quassin against Culex quinquefasciatus. Indian J Med Res 93:324-327

Franqois G, Looveren MV, Timperman G, Chimanuka B, Assi LA, Holenz J, Bringmann G (1996) Larvicidal activity of the naphthylisoquinoline alkaloid dioncophylline A against the malaria vector Anopheles stephensi. J Ethnopharmacol 54:125-130

Ghosh A, Chowdhury N, Chandra G (2008) Laboratory evaluation of a phytosteroid compound of mature leaves of day jasmine (Solanaceae: Solanales) against larvae of Culex quinquefasciatus (Diptera: Culicidae) and nontarget organisms. Parasitol Res $103: 271-277$

Ghosh A, Chowdhury N, Chandra G (2012) Plant extracts as potential mosquito larvicides. Indian J Med Res 135:581-598

Ghosh A, Chandra G (2006) Biocontrol efficacy of Cestrum diurnum L. (Solanaceae: Solanales) against the larval forms of Anopheles stephensi. Nat Prod Res 20:371-379

Gillij YG, Gleiser RM, Zygadlo JA (2008) Mosquito repellent activity of essential oils of aromatic plants growing in Argentina. Biores Technol 99:2507-2515 
Govindarajan M, Jebanesan A, Pushpanathan T, Samidurai K (2008) Studies on effect of Acalypha indica L. (Euphorbiaceae) leaf extracts on the malarial vector, Anopheles stephensi Liston (Diptera: Culicidae). Parasil Res 103:691-695

Greger H (1984) Alkamides: Structural relationship, distribution and biological activity. Planta Med 50:366-375

Grodner ML (1997) http://aapse.ext.vt.edu/archives/97AAPCO_report

Haghbeen K, Mozaffarian V, Ghaffari F, Pourazeezi E, Saraji M, Joupari MD (2006) Lithospermum officinale callus produces shikalkin. Biol Bratislava 61:463-467

Hemingway J (2004) Taking aim at mosquitoes. Nature 430:936

Hori M (2003) Repellency of essential oils against the cigarette beetle, Lasioderma serricorne (Fabricius) (Coleoptera: Anobiidae). Appl Entomol Zool 38:467-473

Hossam E-DMZ, Samir AMA (2010) Larvicidal, adulticidal and growth inhibitory effects of monoterpenes on Culex pipiens L. (Diptera: Culicidae). J Agric Res Kafer El-Sheikh Univ 36:385-401

Ioset JR, Marston A, Gupta MP, Hostettmann K (1998) Antifungal and larvicidal meroterpenoid naphthoquinones and a naphthoxirene from the roots of Cordia linnaei. Phytochemistry 47:729-734

Ioset JR, Marston A, Gupta MP, Hostettmann K (2001) Five new prenylated stilbenes from the root bark of Lonchocarpus chiricanus. J Nat Prod 64:710-715

Ioset JR, Marston A, Gupta MP, Hostettmann K (2000) Antifungal and larvicidal cordiaquinones from the roots of Cordia curassavica. Phytochemistry 53:613-617

Isman MB (1997) Neem and Other Botanical Insecticides: Barriers to Commercialization. Phytoparasitica 25:339-344

Isman MB (2000) Plant essential oils for pest and disease management. Crop Prot 19:603-608 
Jackson FLC, Behkeit SS, EL-Etr SM, Quach NK (1990) Larvicidal effects of grain sorghum (Sorghum bicolor) seedling extracts upon Culex pipiens larvae. J Am Mosq Control Assoc 6:500-503

Jalees S, Sharma SK, Rahman SJ, Verghese T (1993) Evaluation of insecticidal properties of an indigenous plant, Cannabis sativa L., against mosquito larvae under laboratory conditions. J Entomol Res 17:117-120

James AA (1992) Mosquito molecular genetics:the hands that feed bite back. Science 257:3738

Jang YS, Baek BR, Yang YC, Kim MK, Lee HS (2002) Larvicidal activity of leguminous seeds and grains against Aedes aegypti and Culex pipiens pallens (Diptera: Culicidae). J Am Mosq Control Assoc 18:210-213

Jantan I, Yalvema MF, Ahmad NW, Jamal JA (2005) Insecticidal activities of the leaf oils of eight Cinnamomum species against Aedes aegypti and Aedes albopictus. Pharm Biol 43:526-532

Jayaprakasha GK, Singh RP, Pereira J, Sakariah KK (1997) Limonoids from Citrus reticulata and their moult inhibiting activity in mosquito Culex quinquefasciatus larvae. Phytochemistry 44:843-846

Jo ECCA, Silverra ER, Lima MAS, Neto MA, Andrade ILD, Lima MALA (2003) Insecticidal activity and chemical composition of volatile oils from Hyptis martiusii Benth. J Agric Food Chem 51:3760-3762

Joseph CC, Ndoile MM, Malima RC, Nkunya MHH (2004) Larvicidal and mosquitocidal extracts, a coumarin, isoflavonoids and pterocarpans from Neorautanenia mitis. Trans Roy Soc Trop Med Hygiene 98:451-455

Jung J-C, Moon H-I (2011) Larvicidal activity of 4-hydroxycoumarin derivatives against Aedes aegypti. Pharmaceutical Biology 49:190-193 
Kabir KE, Khan AR, Mosaddik MA (2003) Goniothalamin a potent mosquito larvicide from Bryonopsis laciniosa L. J Appl Entomol 127:112-115

Kalyanasundaram M, Babu CJ (1982) Biologically active plant extracts as mosquito larvicides. Indian J Med Res 76:102-106

Kamaraj C, Bagavan A, Elango G, Zahir AA, Rajkumar G, Mariamuthu S, Santhoshkumar T, Rahuman AA (2011) Larvicidal activity of medicinal plant extracts against Anopheles stephensi and Culex tritaeniorhynchus. Indian J Med Res 134:101-106

Kamaraj C, Rahuman AA, Bagavan A, Zahir AA, Elango G, Kandan P, Rajakumar G, Marimuthu S, Santhoshkumar T (2010) Larvicidal efficacy of medicinal plant extracts against Anopheles stephensi and Culex quinquefasciatus (Diptera: Culicidae). Trop Biomed 27:211-219

Kamaraj C, Rahuman AA (2010) Larvicidal and adulticidal potential of medicinal plant extracts from south India against vectors. Asian Pacific J Trop Med 3:948-953

Kannathasan K, Senthilkumar A, Venkatesalu V (2011) Mosquito larvicidal activity of methyl-p-hydroxybenzoate isolated from the leaves of Vitex trifolia Linn. Acta Tropica 120:115-118

Karmegam N, Sakthivadivel M, Anuradha V, Daniel T (1997) Indigenous plant extracts as larvicidal agentsagainst Culex quinquefasciatus Say. Biores Technol 59:137-140

Karunamoorthi K, Mulelam A, Wassie F (2009) Assessment of knowledge and usage custom of traditional insect/mosquito repellent plants in Addis Zemen Town, South Gonder, North Western Ethiopia. J Ethnopharmacol 121:49-53

Kaushik R, Saini P (2008) Larvicidal activity of leaf extract of Millingtonia hortensis (Family: Bignoniaceae) against Anopheles stephensi, Culex quinquefasciatus and Aedes aegypti. J Vector Borne Dis 45:66-69

Kelm MA, Nair MG (1998) Mosquitocidal compounds and a triglyceride, 1,3- dilinoleneoyl2-palmitin, from Ocimum sanctum. J Agric Food Chem 46:3092-3094 
Kelm MA, Nair MG, Schutzki RA (1997) Mosquitocidal Compounds from Magnolia Salicifolia. Int J Pharmacog 35:84-90

Kern JR, Cardellina JH (1982) Native American Medicinal Plants, Falcarindiol and 3-Omethyl-falcarindiol from Osmorhiza occidentalis. J Nat Prod 45:774-776

Khanna G, Kannabiran K (2007) Larvicidal effect of Hemidesmus indicus, Gymnema sylvestre, and Eclipta prostrata against Culex qinquifaciatus mosquito larvae. Afr $\mathrm{J}$ Biotechnol 6:307-311

Khanna VG, Kannabiran K, Rajakumar G, Rahuman AA, Santhoshkumar T (2011) Biolarvicidal compound gymnemagenol isolated from leaf extract of miracle fruit plant, Gymnema sylvestre (Retz) Schult against malaria and filariasis vectors. Parasitol Res 109:1373-1386

Kihampa C, Nkunya MHH, Joseph CC, Magesa SM (2010) Antimosquito Phenylpropenoids from the Stem and Root Barks of Uvariodendron pycnophyllum (Diels). J Appl Sci Environ Manage 14:29-32

Kiprop AK, Kiprono PC, Rajab MS, Kosgei MK (2007) Limonoids as Larvicidal Components against Mosquito Larvae (Aedes aegypti Linn.). Z Naturforsch 62c:826828

Kiran SR, Devi PS (2007) Evaluation of mosquitocidal activity of essential oil and sesquiterpenes from leaves of Chloroxylon swietenia DC. Parasitol Res 101:413-418

Kishore N, Mishra BB, Tiwari VK, Tripathi V (2010) Difuranonaphthoquinones from Plumbago zeylanica roots. Phytochem Lett 3:62-65

Kovendan K, Murugan K, Vincent S (2012) Evaluation of larvicidal activity of Acalypha alnifolia Klein ex Willd. (Euphorbiaceae) leaf extract against the malarial vector, Anopheles stephensi, dengue vector, Aedes aegypti and Bancroftian filariasis vector, Culex quinquefasciatus (Diptera: Culicidae). Parasitol Res 110:571-581 
Kumar PM, Murugan K, Kovendan K, Panneerselvam C, Kumar KP, Amerasan D, Subramaniam J, Kalimuthu K, Nataraj T (2012) Mosquitocidal activity of Solanum xanthocarpum fruit extract and copepod Mesocyclops thermocyclopoides for the control of dengue vector Aedes aegypti. Parasitol Res 111:609-618

Kumar A, Dutta GP (1987) Indigenous plant oils as larvicidal agents against Anopheles stephensi. Curr Sci 56:959-960

Kuo PM, Chu FH, Chang ST, Hsiao WF, Wang SY (2007) Insecticidal activity of essential oil from Chamaecyparis formosensis Matsum. Hlzforschung 61 :595-599

Lee KH, Huang ES, Piandosi C, Pagano J (1971) Cytotoxicity of Sesquiterpene Lactones. Cancer Res 31:1649-1654

Lee SE (2000) Mosquito larvicidal activity of pipernonaline, a piperidine alkaloid derived from long pepper, Piper longum. J Am Mosq Control Assoc 16:245-247

Lee SE, Park BS, Kim MK, Choi WS, Kim HT, Cho KY, Lee SG, Lee HS (2001) Fungicidal activity of pipernonaline, a piperidine alkaloid derived from long pepper, Piper longum L., against phytopathogenic fungi. Crop Prot 20:523-528

Liu ZL, He Q, Chu SS, Wang CF, Du SS, Deng ZW (2012) Essential oil composition and larvicidal activity of Saussurea lappa roots against the mosquito Aedes albopictus (Diptera: Culicidae). Parasitol Res 110:2125-2130

Lukwa N, Nyazema NZ, Curtis CF, Mwaiko GL, Chandiwana SK (1999) People's perceptions about malaria transmission and control using mosquito repellent plants in a locality in Zimbabwe. Cent Afr J Med 45 :64-68

Madhu SK, Vijayan VA, Shaukath AK (2011) Bioactivity guided isolation of mosquito larvicide from Piper longum. Asian Pacific Journal of Tropical Medicine 4:112-116

Madhua SK, Shaukath AK, Vijayan VA (2010) Efficacy of bioactive compounds from Curcuma aromatica against mosquito larvae. Acta Tropica 113:7-11 
Maniafu BM, Wilber L, Ndiege IO, Wanjala CC, Akenga TA (2009) Larvicidal activity of extracts from three Plumbago spp against Anopheles gambiae. Mem I Oswaldo Cruz $104: 813-817$

Mansour SA, Messeha SS, EL-Gengaihi SE (2000) Botanical biocides. 4. Mosquitocidal activity of certain Thymus capitatus constituents. J Nat Toxins 9:49-62

Markouk M, Bekkouche K, Larhsini M, Bousaid M, Lazrek HB, Jana M (2000) Evaluation of some Moroccan medicinal plant extracts for larvicidal activity. J Ethnopharmacol $73: 293-297$

Matasyoh JC, Wathuta EM, Kairuki ST, Chepkorir R, Kavulani J (2008) Aloe plant extracts as alternative larvicides for mosquito control. Afr J Biotech 7:912-915

Maurya P, Mohan L, Sharma P, Batabyal L, Srivastava CN (2007) Larvicidal efficacy of Aloe barbadensis and Cannabis sativa against the malaria vector Anopheles stephensi (Diptera: Culicidae). Entomol Res 37:153-156

Mgbemena IC (2010) Comparative evaluation of larvicidal potentials of three plant extracts on Aedes aegypti. J Am Sci 6:435-440

Michaelakis A, Strongilos AT, Bouzas EA, Koliopoulos G, Couladouros EA (2009) Larvicidal activity of naturally occurring naphthoquinones and derivatives against the West Nile virus vector Culex pipiens. Parasitol Res 104:657-662

Miles JE, Ramsewak RS, Nair MG (2000) Antifeedant and Mosquitocidal Compounds from Delphinium x cultorum Cv. Magic Fountains Flowers. J Agric Food Chem 48:503-506

Mishra BB, Kishore N, Tiwari VK, Singh DD, Tripathi V (2010) A novel antifungal anthraquinone from seeds of Aegle marmelos Correa (family-Rutaceae). Fitoterapia $81: 104-107$

Mishra BB, Singh DD, Kishore N, Tiwari VK, Tripathi V (2010) Antifungal constituents isolated from the seeds of Aegle marmelos. Phytochemistry 71:230-234 
Mishra BB, Tiwari VK (2011) Natural products: An evolving role in future drug discovery, Eur J Med Chem 46:4769-4807

Miyazawa M, Shimamura H, Bhuva RC, Nakamura S, Kameoka H (1996) Antimutagenic activity of falcarindiol from Peucedanum praeruptorum. J Agric Food Chem 44:34443448

Mohan L, Sharma P, Shrivastava CN (2006) Evaluation of Solanum xanthocarpum extract as a synergist for cypermethrin against larvae of filarial vector Culex quinquefasciatus (Say). Entomol Res 36:220-225

Moawed HAM (1998) MSc Thesis, Faculty of Science-Dmietta, Mansoura University

Momin RA, Nair MG (2001) Mosquitocidal, nematicidal, and antifungal compounds from Apium graveolens L. seeds. J Agric Food Chem 49:142-145

Momin RA, Nair MG (2002) Pest-Managing Efficacy of trans-Asarone Isolated from Daucus carota L. Seeds. J Agric Food Chem 50:4475-4478

Momin RA, Ramsewak RS, Nair MG (2000) Bioactive Compounds and 1,3-Di[(cis)-9octadecenoyl]-2-[(cis,cis)-9,12-octadecadienoyl]glycerol from Apium Graveolens L. Seeds. J Agric Food Chem 48:3785-3788

Monzon RB, Alvior JP, Luczon LL, Morales AS, Mutuc FE (1994) Larvicidal potential of five Philippine plants against Aedes aegypti (Linnaeus) and Culex quinquefasciatus (Say). Southeast Asian J Trop Med Public Health 25:755-759

Mulla MS, Su T (1999) Activity and biological effects of neem products against arthropods of medical and veterinary importance. J Am Mosq Control Assoc 15:133-152

Mullai K, Jebanesan A, Pushpanathan T (2008) Mosquitocidal and repellent activity of the leaf extract of Citrullus vulgaris (cucurbitaceae) against the malarial vector, Anopheles stephensi liston (diptera culicidae). Euro Rev Med Pharma Sci 12:1-7 
Mullai K, Jebanesan A (2007) Larvicidal, ovicidal and repellent activities of the leaf extract of two cucurbitacious plants against filarial vector Culex quinquefasciatus (Say) (Diptera: Culicidae). Trop Biomed 24:1-6

Mungkornasawakul P, Pyne SG, Jatisatienr A, Supyen D, Jatisatienr C, Lie W, Ung AT, Skelton BW, White AH (2004) Phytochemical and larvicidal studies on Stemona curtisii: structure of a new pyrido[1,2-a]azepine stemona alkaloid. J Nat Prod 67:675677

Nair MG, Putnam AR, Mishra SK, Mulks MH, Taft WH, Keller JE, Miller JR, Zhu PP, Meinhart JD, Lynn DG (1989) Faeriefungin: a new broad-spectrum antibiotic from Streptomyces griseus var. autotrophicus. J Nat Prod 52:797-809

Nathan SS, Hisham A, Jayakumar G (2008) Larvicidal and growth inhibition of the malaria vector Anopheles stephensi by triterpenes from Dysoxylum malabaricum and Dysoxylum beddomei. Fitoterapia 79:106-111

Nathan SS, Kalaivani K, Murugan K (2005) Effects of neem limonoids on the malaria vector Anopheles stephensi Liston (Diptera: Culicidae). Acta Trop 96:47-55

Nawamaki K, Kuroyanagi M (1996) Sesquiterpenoids from Acorus calamus as germination inhibitors. Phytochemistry 43:1175-1182

Nazar S, Ravikumar S, Williams GP, Ali MS, Suganthi P (2009) Screening of Indian costal plant extracts for larvicidal activity of Culex quinquefasciatus. Indian J Sci Technol 2:24-27

Ndungu M, Hassanali A, Hooper AM, Chhabra S, Miller TA, Paul RL, Torto B (2003) Ring A- seco mosquito larvicdal limonoids from Turraea wakefeldii. Phytochemistry 64:817-823

Ndungu MW, Kaoneka B, Hassanali A, Lwande W, Hooper AM, Tayman F, Zerbe O, Torto B (2004) New mosquito larvicidal tetranortriterpenoids from Turraea wakefieldii and Turraea floribunda. J Agric Food Chem 52:5027-5031 
Nerio LS, Olivero-Verbel J, Stashenko E (2010) Repellent activity of essential oils: A review. Biores Technol 101:372-378

Nikkon F, Salam KA, Yeasmin T, Mosaddik A, Khondkar P, Haque ME (2010) Mosquitocidal triterpenes from the stem of Duranta repens. Pharmaceutical Biology 48:264-268

Nunes e Vasconcelos J, Santiago GMP, Lima JQ, Mafezoli J, Gomes de Lemos TL, Lopes da Silva FR, Lima MAS, Pimenta ATA, Arriaga RB-F, Campos AM, Cesarin-Sobrinho D (2012) Rotenoids from Tephrosia toxicaria with larvicidal activity against Aedes aegypti, the main vector of dengue fever. Quim Nova 35:1097-1100

Odalo JO, Omolo MO, Malebo H, Angira J, Njeru PM, Ndiege IO, Hassanali A (2005) Repellency of essential oils of some plants from the Kenyan coast against Anopheles gambiae. Acta Trop 95:210-218

Omena MC, Navarro DM, de Paula JE, de Lima FMR, Santana AE (2007) Larvicidal activities against Aedes aegypti of Brazilian medicinal plants. Bioresource Technol $98: 2549-2556$

Omena MC, Bento ES, Paula JE, Santana AEG (2006) Larvicidal Diterpenes from Pterodon polygalaeflorus.Vector-Borne And Onotic Diseases 6:216-222

Palsson K, Jaenson TG (1999) Plant products used as mosquito repellents in Guinea Bissau, West Africa. Acta Trop $72: 39-52$

Park H-M, Park Il-Kwon (2012) Larvicidal activity of Amyris balsamifera, Daucus carota and Pogostemon cablin essential oils and their components against Culex pipiens pallens. J Asia-Pacific Entomol 15:631-634

Park I-K, Shin S-C, Kim C-S, Lee H-J, Choi W-S, Ahn Y-J (2005) Larvicidal Activity of Lignans Identified in Phryma leptostachya Var. asiatica Roots against Three Mosquito Species. J Agric Food Chem 53:969-972 
Park IK, Lee SG, Shin SC, Park JD, Young-Joon AHN (2002) Larvicidal activity of isobutylamides identified in Piper nigrum fruits against three mosquito species. J Agric Food Chem 50:1866-1870

Perich MJ, Wells C, Bertsch W, Tredway KE (1995) Isolation of the insecticidal components of Tagetes minuta (Compositae) against mosquito larvae and adults. J Am Mosq Control Assoc 11:307-310

Perrucci S, Cioni PL, Cascella A, Maccioni F (1997) Therapeutic efficacy of linalool for the topical treatment of parasitic otitis caused by Psoroptes cuniculi in the rabbit and in the goat. Med Vet Entomol 11:300-302

Pinto ACS, Nogueira KL, Chaves FCM, Silva LV Souza da, Tadei WP, Pohlit AM (2012) Adulticidal Activity of Dillapiol and Semi-synthetic Derivatives of Dillapiol against Aedes aegypti (L.) (Culicidae). J Mosq Res 2:1-7

Pizarro AP, Oliveira FAM, Parente JP, Melo MT, dosSantos CE, Lima PR (1999) Utilization of the waste of sisal industry in the control of mosquito larvae. Rev Soc Bras Med Trop $32: 23-29$

Prabhakar K, Jebanesa A (2004) Larvicidal efficacy of some cucurbitacious plant leaf extracts against Culex quinquefasciatus. Bioresource Tech 95:113-114

Prajapati V, Tripathi AK, Aggarwal KK, Khanuja SPS (2005) Insecticidal, repellent and oviposition-deterrent activity of selected essential oils against Anopheles stephensi, Aedes aegypti and Culex quinquefasciatus. Biores Technol 96:1749-1757

Pridgeon JW, Meepagala KM, Becnel JJ, Clark GG, Pereira RM, Linthicum KJ (2007) Structure-activity relationships of 33 piperidines as toxicants against female adults of Aedes aegypti (Diptera: Culicidae). J Med Entomol 44:263-269

Pushpalatha E, Muthukrishnan J (1999) Efficacy of two tropical plant extracts for the control ofmosquitoes. J Appl Entomol 123:369-373 
Pushpanathan T, Jebanesan A, Govindarajan M (2008) The essential oil of Zingiber officinalis Linn (Zingiberaceae) as a mosquito larvicidal and repellent agent against the filarial vector Culex quinquefasciatus Say (Diptera: Culicidae). Parasitol Res 102:12891291

Puyvelde VL, Dekimpe N, Mudaharanwa JP, Gasiga A, Schamp N, Declerq JP, Meerssche VM (1987) Isolation and structural elucidation of potentially insecticidal and acaricidal isoflavone-type compounds from Neorautanenia mitis. J Nat Prod 50:349-356

Radwan MA, El-Zemity SR, Mohamed SA, Sherby SM (2008) Larvicidal activity of some essential oils, monoterpenoids and their corresponding $N$-methyl carbamate derivatives against Culex pipiens (Diptera: Culicidae). Int J Trop Insect Sci 28:61-68

Raghavendra K, Singh SP, Subbarao SK, Dash AP (2009) Laboratory studies on mosquito larvicidal efficacy of aqueous \& hexane extracts of dried fruit of Solanum nigrum Linn. Indian J Med Res 130:74-77

Rahuman AA, Gopalakrishnan G, Ghouse BS, Arumugam S, Himalayan B (2000) Effect of Feronia limonia on mosquito larvae. Fitoterapia 71:553-555

Rahuman AA, Gopalakrishnan G, Venkatesan P., Geetha K, Bagavan A (2008) Mosquito Larvicidal Activity of Isolated Compounds from the Rhizome of Zingiber officinale. Phytother Res 22:1035-1039

Rahuman AA, Venkatesan P (2008) Larvicidal efficacy of five cucurbitaceous plant leaf extracts against mosquito species. Parasitol Res 103:133-139

Rahuman AA, Gopalakrishnan G, Venkatesan P, Geetha K (2008) Isolation and identification of mosquito larvicidal compound from Abutilon indicum (Linn.) Sweet. Parasitol Res 102:981-988

Rajmohan D, Ramaswamy M (2007) Evaluation of larvicidal activity of the leaf extract of a weed plant, Ageratina adenophora, against two important species of mosquitoes, Aedes aegypti and Culex quinquefasciatus. Afr J Biotech 6:631-638 
Rajkumar S, Jebanesan A (2008) Bioactivity of flavonoid compounds from Poncirus trifoliata L. (Family: Rutaceae) against the dengue vector, Aedes aegypti L. (Diptera: Culicidae). Parasitol Res 104:19-25

Rajkumar S, Jebanesan A (2005) Larvicidal and adult emergence inhibition effect of Centella asiatica Brahmi (umbelliferae) against mosquito Culex quinquefasciatus Say (Diptera: Culicidae). Afr J Biomed Res 8:31-33

Rajkumar S, Jebanesan A (2009) Larvicidal and oviposition activity of Cassia obtusifolia Linn (Family: Leguminosae) leaf extract against malarial vector, Anopheles stephensi Liston (Diptera: Culicidae). Parasitol Res 104:337-340

Rajkumar S, Jebanesan A (2004) Mosquitocidal activity of octacosane from Moschosma polystachyum L. (Lamiaceae). J Ethnopharmacol 90:87-89

Rajkumar S, Jebanesan A (2005) Repellency of volatile oils from Moschosma polystachyum and Solanum xanthocarpum against filarial vector Culex quinquefasciatus say. Trop Biomed 22:139-142

Ramsewak RS, Nair MG, DeWitt DL, Mattson WJ, Zasada J (1999) Phenolic glycosides from Dirca palustris. J Nat Prod 62:1558-1561

Ramsewak RS, Nair MG, Murugesan S, Mattson WJ, Zasada J (2001) Insecticidal fatty acids and triglycerides from Dirca palustris. J Agric Food Chem 49:5852-5856

Ramsewak RS, Nair MG, Strasburg GM, DeWitt DL, Nitiss JL (1999) Biologically active carbazole alkaloids from Murraya koenigii. J Agric Food Chem 47:444-447

Ranaweera SS (1996) Mosquito-Larvicidal Activity of some Sri Lankan Plants. J Natl Sci Counc Sri Lanka 24:63-70

Ratnayake R, Karunaratne V, Bandara BMR, Kumar V, MacLeod JK, Simmonds P (2001) Two new lactones with mosquito larvicidal activity from three Hortonia species. J Nat Prod 64:376-378 
Rawani A, Ghosh A, Chandra G (2010) Mosquito larvicidal activities of Solanum nigrum L. leaf extract against Culex quinquefasciatus Say. Parasitol Res 107:1235-1240

Rawani A, Mallick Haldar K, Ghosh A, Chandra G (2009) Larvicidal activities of three plants against filarial vector Culex quinquefasciatus Say (Diptera: Culicidae). Parasitol Res 105:1411-1417

Ribeiro KAL, Carvalho CM, Molina MT, Lima EP, Lopez-Montero E, Reys JRM, Oliveira MBF, Pinto AV, Santana AEG, Goulart MOF (2009) Activities of naphthoquinones against Aedes aegypti (Linnaeus, 1762) (Diptera: Culicidae), vector of dengue and Biomphalaria glabrata (Say, 1818), intermediate host of Schistosoma mansoni. Acta Trop 111:44-50

Rice PJ, Coats JR (1994) Insecticidal properties of monoterpenoid derivatives to the house fly (Diptera: Muscidae) and red flour beetle (Coleoptera: Tenebrionidae). Pesticide Science 41:195-202

Roark RC (1947) Some promising insecticidal plants. Econ Bot 1:437-445

Rodrigues AMS, Paula JE, Roblot F, Fournet A, Espíndola LS (2005) Larvicidal activity of Cybistax antisyphilitica against Aedes aegypti larvae. Fitoterapia 76:755-757

Roth GN, Chandra A, Nair MG (1998) Novel bioactivities of Curcuma longa constituents. J Nat Prod 61:542-545

Sagnou M, Mitsopoulou KP, Koliopoulos G, Pelecanou M, Couladouros EA, Michaelakis A (2012) Evaluation of naturally occurring curcuminoids and related compounds against mosquito larvae. Acta Tropica 123:190-195

Sakthivadivel M, Daniel T (2008) Evaluation of certain insecticidal plants for the control of vector mosquitoes viz. Culex quinquefasciatus, Anopheles stephensi and Aedes aegypti. Appl Entomol Zool 43:57-63 
Samidurai K, Jebanesan A, Saravanakumar A, Govindarajan M, Pushpanathan T (2009) Larvicidal, ovicidal and repellent activities of pemphis acidula forst against filarial and Dengue vector mosquitoes. Academic Journal of Entomology 2:62-66

Schmutterer H (1990) Properties and potential of natural pesticides from the neem tree, Azadirachta indica. Annu Rev Entomol 35:271-297

Severini C, Rom R, Marinucci M, Rajmond M (1993) Mechanisms of insecticide resistance in field populations of Culex pipiens from Italy. J Am Mosq Control Assoc 9:164-168

Seyoum A, Palsson K, Kunga S, Kabiru EW, Lwande W, Killeen GF, Hassanali A, Knols BG (2002) Traditional use of mosquito-repellent plants in western Kenya and their evaluation in semi-field experimental huts against Anopheles gambiae: ethnobotanical studies and application by thermal expulsion and direct burning. Trans Roy Soc Trop Med Hygiene 96:225-231

Shaalan E, Canyon D, Faried MW, Abdel-Wahab H, Mansour A (2005) A review of botanical phytochemicals with mosquitocidal potential. Environ Int 31:1149-1166

Shaalan E, Canyon DV, Faried MW, Abdel-Wahab H, Mansour A (2003) The Annual Queensland Health and Medical Scientific Meeting, "Making It Better: Encouraging health research and innovation"' 25-26 November, Brisbane

Sharma P, Mohan L, Srivastava CN (2006) Phytoextract-induced developmental deformities in malaria vector. Bioresource Tech 97:1599-1604

Sharma M, Saxena RC (1994) Phytotoxicological evaluation of Tagetes erectes on aquatic stages of Anopheles stephens Ind J Malar 31:21-26

Siddiqui BS, Afshan F, Faizi S, Naqvi SN-ul-H, Tariq RM (2002) Two New Triterpenoids from Azadirachta indica and Their Insecticidal Activity. J Nat Prod 65:1216-1218

Singh RK, Dhiman RC, Mittal PK (2006) Mosquito larvicidal properties of Momordica charantia Linn (Family: Cucurbitaceae). J Vect Borne Dis 43:88-91 
Sivagnaname S, Kalyanasundaram M (2004) Laboratory evaluation of Methanolic extract of Atlanta monophylla (Family: Rutaceae) against immature stage of mosquitoes and nontarget organisms. Mem Inst Oswaldo Cruz 99:115-158

Soliman BA, El-Sherif LS (1995) Larvicidal effect of some plant oils on mosquito Culex pipiens L (Diptera: Culicidae). J Egypt Ger Soc Zool 16:161-169

Sreelatha TT, Hymavathi A, Murthy JM, Rani PU, Rao JM, Babu KS (2010) Bioactivityguided isolation of mosquitocidal constituents from the rhizomes of Plumbago capensis. Bioorganic \& Medicinal Chemistry Letters 20:2974-2977

Sukumar K, Perich MJ, Boobar LR (1991) Botanical derivatives in mosquito control: a review. J Am Mosq Contr Assoc 7:210-237

Sun R, Sacalis JN, Chin CK, Still CC (2001) Bioactive aromatic compounds from leaves and stems of Vanilla fragrans. J Agric Food Chem 49:5161-5164

Swain T (1977) Secondary Compounds as Protective Agents. Annu Rev Plant Physiol 28:479-501

Thangam TS, Kathiresan K (1991) Mosquito larvicidal activity of marine plants extracts with synthetic insecticides. Bot Mar 34:537-539

Thomas CJ, Callaghan A (1999) The use of Garlic (Allium Sativa) and Lemon Peel (Citrus Limon) Extracts as Culex Pipiens Larvacides: Persistence and Interaction with an Organophosphate Resistance Mechanism. Chemosphere 39:2489-2496

Tolle MA (2009) Mosquito-borne diseases. Curr Probl Pediatr Adolesc Health Care 39:97140

Traboulsi AF, El-Haj S, Tueni M, Taoubi K, Nader NA, Mrad A (2005) Repellency and toxicity of aromatic plant extracts against the mosquito Culex pipiens molestus (Diptera: Culicidae). Pest Manag Sci 61:597-604

Trongtokit Y, Rongsriyam Y, Komalamisra N, Apiwathnasorn C (2005) Comparative Repellency of 38 Essential Oils against Mosquito Bites. Phytother Res 19:303-309 
Tunon H, Thorsell W, Mikiver A, Malander I (2006) Arthropod repellency, especially tick (Ixodes ricinus), exerted by extract from Artemisia abrotanum and essential oil from flowers of Dianthus caryophyllum. Fitoterapia 77:257-261

Urbanek H, Bergier K, Saniewski M, Patykowski J (1996) Effect of jasmonates and exogenous polysaccharides on production of alkannin pigments in suspension cultures of Alkanna tinctoria. Plant Cell Rep 15:637-641

Vasudevan K, Malarmagal R, Charulatha H, Saraswatula VL, Prabakaran K (2009) Larvicidal effects of crude extracts of dried ripened fruits of Piper nigrum against Culex quinquefasciatus larval instars. J Vector Borne Dis 46:153-156

Wandscheer CB, Duque JE, daSilva MAN, Fukuyama Y, Wohlke JL, Adelmann J, Fontana JD (2004) Larvicidal action of ethanolic extracts from fruit endocarps of Melia azedarach and Azadirachta indica against the dengue mosquito Aedes aegypti. Toxicon 44:829

Wang Z, Kim J-R, Wang M, Shu S, Ahn Y-J (2012) Larvicidal activity of Cnidiummon nieri fruit coumarins and structurally related compounds against insecticide-susceptible and insecticide-resistant Culex pipiens pallens and Aedes aegypti. Pest Manag Sci 68:10411047

Wood A (2003) http://www.alanwood.net/pesticides/index

Xiao X-m, Hu Z-n, Shi B-j, Wei S-p, Wu W-j (2012) Larvicidal activity of lignans from Phryma leptostachya L. against Culex pipiens pallens. Parasitol Res 110:1079-1084

Yang YC, Lim MY, Lee HS (2003) Emodin isolated from Cassia obtusifolia (Leguminosae) seed shows larvicidal activity against three mosquito species. J Agri Food Chem $51: 7629-7631$

Yang P, Yajun M, Zheng S (2005) Adulticidal activity of five essential oils against Culex pipiens quinquefasciatus. J Pest Sci 30:84-89 
Yang YC, Lee SG, Lee HK, Kim MK, Lee SH, Lee HS (2002) A Piperidine amide extracted from Piper longum L. fruit shows activity against Aedes aegypti mosquito larvae. J Agric Food Chem 50:3765-3767

Yenesew A, Derese S, Midiwo JO, Heydenreich M, Peter MJ (2003) Effect of rotenoids from the seeds of Millettia dura on larvae of Aedes aegypti. Pest Manage Sci 59:1159-1161

Zaridah MZ, NorAzah MA, Rohani A (2006) Mosquitocidal activities of Malaysian plants. J Trop for Sci 18:74-80

Zeng Y, Zhang Y, Weng Q, Hu M, Zhong G (2010) Cytotoxic and Insecticidal Activities of Derivatives of Harmine, a Natural Insecticidal Component Isolated from Peganum harmala. Molecules 15:7775-7791

Ziba C, Slutsker L, Chitsulo L, Steketee RW (1994) Use of malaria prevention measures in Malawian households. Tropical Medicine Parasitology 45:70-73. 